\title{
UTILIZATION OF GEOGRAPHIC INFORMATION SYSTEM FOR RESEARCH, MANAGEMENT, AND EDUCATION IN THE NATURAL RESOURCES MANAGEMENT DEPARTMENT AT CALIFORNIA POLYTECHNIC STATE UNIVERSITY, SAN LUIS OBISPO
}

\author{
A Scholarly Project \\ presented to \\ the Faculty of California Polytechnic State University, \\ San Luis Obispo
}

\begin{abstract}
In Partial Fulfillment
of the Requirements for the Degree

Master of Science in Agriculture

Specialization in Forestry Sciences
\end{abstract}

by

David In Yun

January 2011 
(C) 2011

David In Yun

ALL RIGHTS RESERVED

Page ii 
COMMITTEE MEMBERSHIP

TITLE:

Utilization of Geographic Information System for Research, Management, and Education in the Natural Resources Management Department at California Polytechnic State University, San Luis Obispo

AUTHOR:

David In Yun

DATE SUBMITTED:

January 2011

COMMITTEE CHAIR:

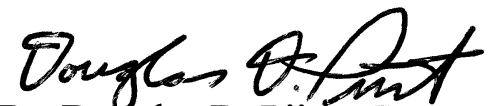

Dr. Douglas D. Piirto, Department Head Natural Resources Management Department

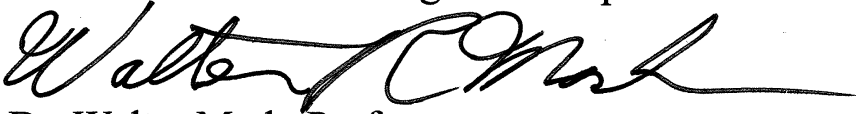

COMMITTEE MEMBER:

Dr. Walter Mark, Professor

Natural Resources Management Department

COMMITTEE MEMBER:

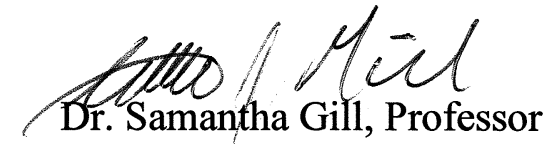

Natural Resources Management Department

COMMITTEE MEMBER:

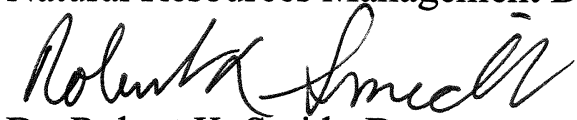

Dr. Robert K. Smidt, Department Chair

Statistics Department 


\author{
ABSTRACT \\ Utilization of Geographic Information System \\ for Research, Management, and Education in the \\ Natural Resources Management Department at \\ California Polytechnic State University, \\ San Luis Obispo \\ David In Yun
}

Geographic Information System (GIS) is “an organized collection of computer hardware, software, geographic data, and personnel designed to efficiently capture, store, update, manipulate, analyze, and display all forms of geographically referenced information” (ESRI, 1997a). The Natural Resources Management Department at California Polytechnic State University, San Luis Obispo, California, hereafter NRM, was one of the early users of GIS technology. Although GIS was primarily used as an educational tool, it was also used for cataloging and displaying resource information for management planning and research projects. As the computing technology advanced, GIS became more powerful and easier to use. NRM faculty and students realized that GIS is the best tool to manage spatial information. In addition, GIS can also manage temporal data. While we are proud of past achievements using GIS, its future prospects for managing time and space information promise even more exciting possibilities and tangible benefits. This scholarly project is a compilation of GIS achievements in NRM. 


\section{ACKNOWLEDGMENTS}

I am truly blessed to have Dr. Douglas D. Piirto, Dr. Walter R. Mark, Dr. Samantha J. Gill, and Dr. Robert K. Smidt as my graduate committee members. This scholarly project would not have been possible without their patience, encouragement, and guidance. I am also very thankful for their caring words during difficult times.

Dr. Brian C. Dietterick introduced me to Geographic Information System (GIS). His encouragement and support for pursuing the GIS field enabled me to complete this scholarly project and ultimately led me to my current job.

I thank all students who asked challenging questions. My GIS knowledge increased significantly due to interactions with Cal Poly students.

My family, Kate, Yale, and Nyle, provides motivation to live well. Their love and respect for me are pure and strong.

I thank God for all his blessings. 
TABLE OF CONTENTS

Page

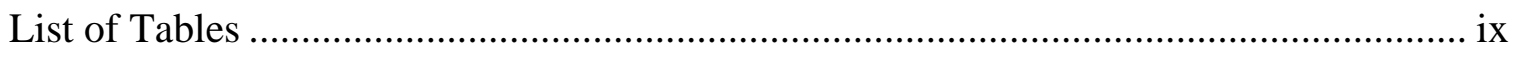

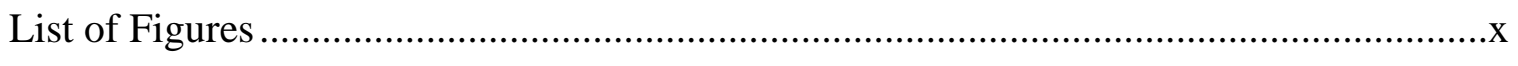

Chapter

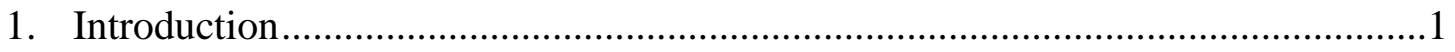

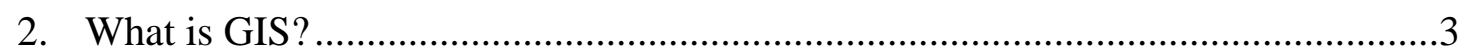

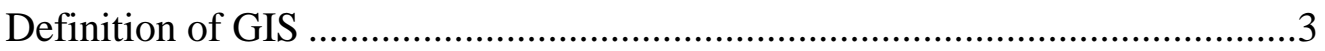

Components of GIS.............................................................................

Types of Data ..........................................................................................

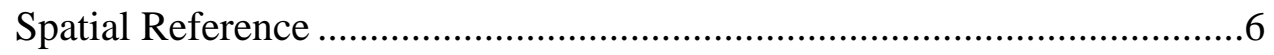

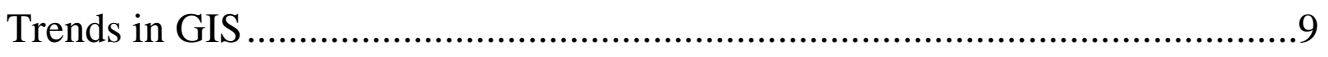

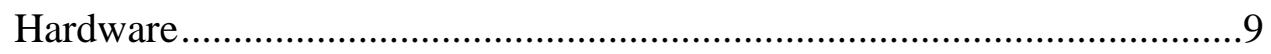

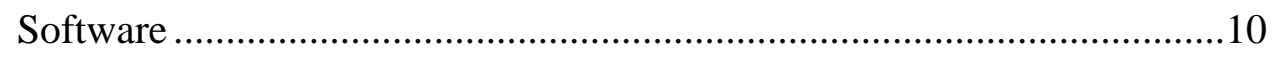

Data

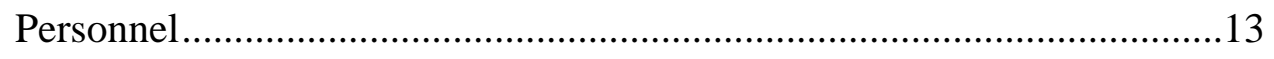

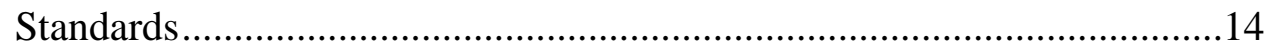

3. GIS in Natural Resources Management...............................................................16

Brief History of GIS in NRM ...................................................................16

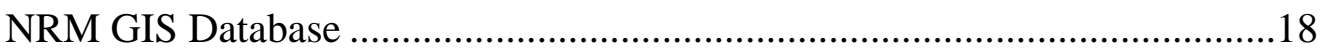

Page vi 
TABLE OF CONTENTS (continued)

Chapter

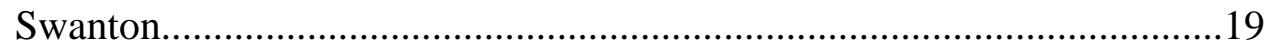

SPR_Boundary..................................................................... 19

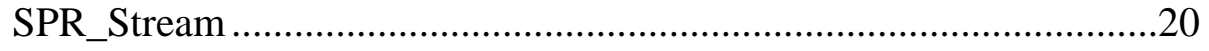

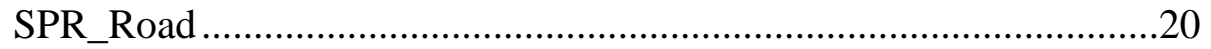

SPR_Vegetation ...................................................................21

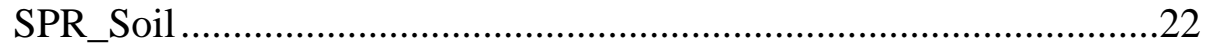

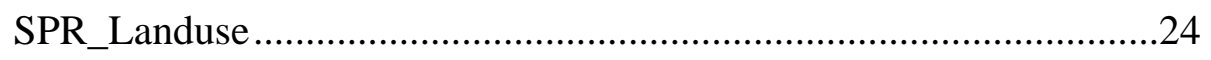

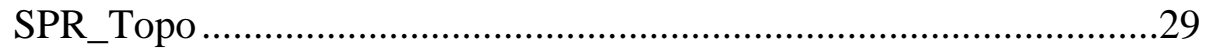

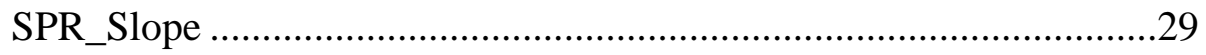

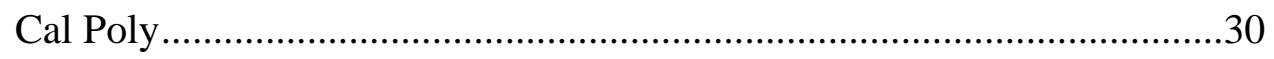

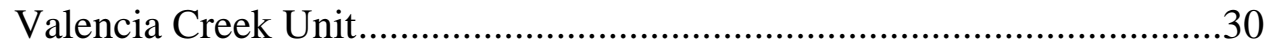

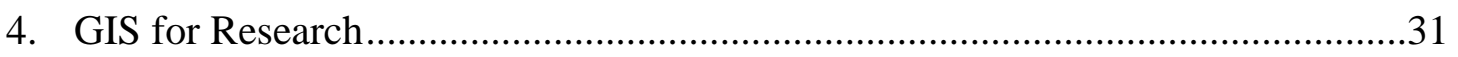

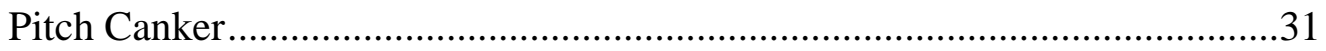

Continuous Forest Inventory Data ....................................................32

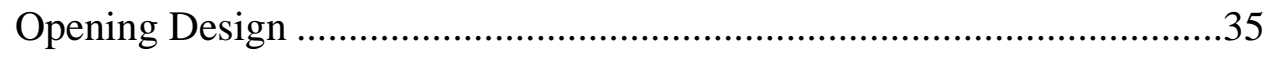

Seedling Planting Design .................................................................35

Monterey Pine Growth and Yield Study...................................................36

Remote Sensing Project ...................................................................36

Page vii 
TABLE OF CONTENTS (continued)

Chapter $\quad$ Page

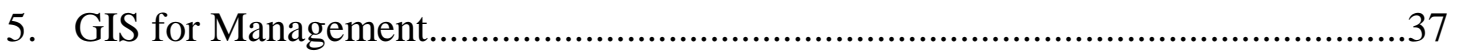

Land Use Map Project ………………...........................................................37

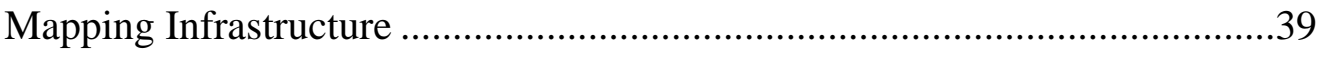

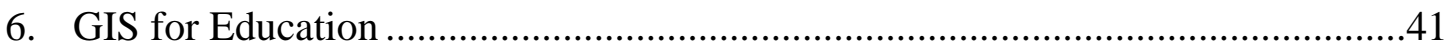

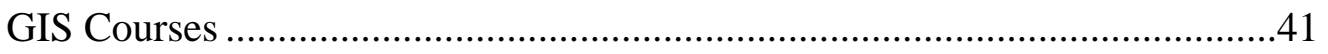

Project Examples ………………………………………….....................43

Chamber of Commerce Mapping.............................................................43

Important Bird Areas (IBA) Mapping ………………........................43

Mapping Oblique Photos of Hillsides...................................................44

7. Conclusions and Recommendations ...................................................................46

Literature Cited ......................................................................................................49

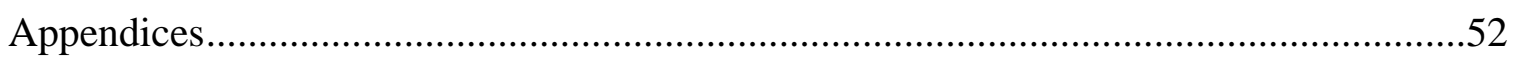

A. List of ESRI User Conference Presentations ............................................................53

B. Mapping Forestry ……………….............................................................62

C. Mapping California's Important Bird Areas.............................................................73

D. DVD of NRM GIS Database and Digital Documents ............................................74

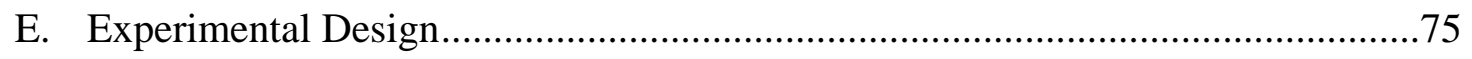




\section{LIST OF TABLES}

Table

Page

1. Commonly Used Projected Coordinate Systems in Swanton Pacific Ranch and Valencia Creek Unit..........................................................

2. Commonly Used Projected Coordinate Systems in San Luis Obispo Area.......8

3. Comparison of Different Geodatabases ......................................................11

4. Attributes of SPR_Vegetation Layer .......................................................21

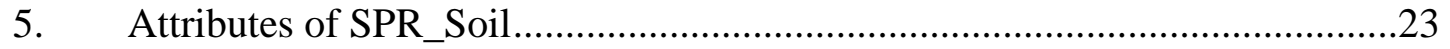

6. Land Use Types and Unit Groups........................................................25

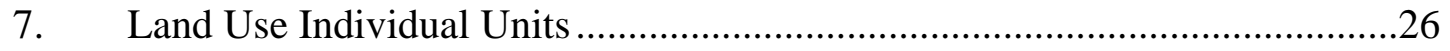

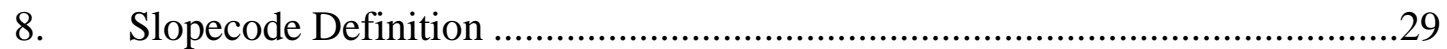

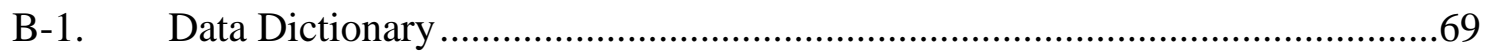

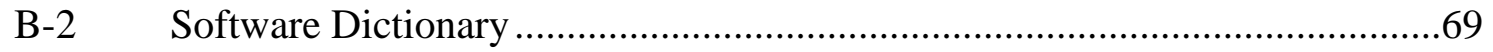

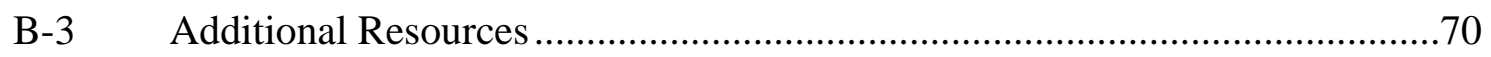

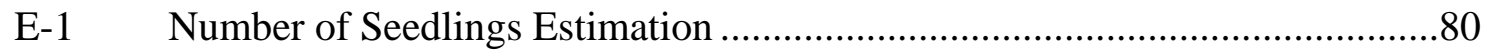




\section{LIST OF FIGURES}

Figure

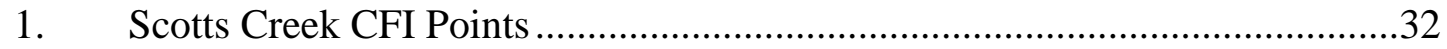

2. Determining the Tree Coordinates...............................................................34

3. Mapping Forestry Cover Page ….............................................................39

4. Screen Capture of the Audubon California IBA Acknowledgement................44

E-1. Group Opening and Treatment Design ..................................................79

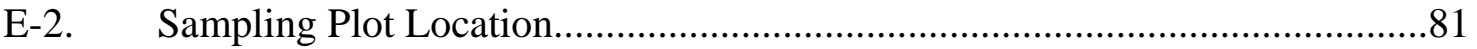




\section{CHAPTER 1}

Introduction

GIS is an information management system used throughout the world. Virtually all disciplines use GIS to collect, analyze, and display geographic information to understand and make better decisions. And yet, it is still not fully understood by many. NRM has used GIS since the early 1990s to map natural resources in Swanton Pacific Ranch (SPR) and California Polytechnic State University, San Luis Obispo (Cal Poly) campus areas. However, use of GIS was mainly limited to mapping, as it was difficult to teach advanced GIS functions. Most students did not pursue GIS beyond their first introduction and those who gained advanced knowledge usually left the university after graduation.

Several NRM graduates are employed by the City of San Luis Obispo and use GIS on a daily basis. David Yun graduated from NRM’s Forest Resources Management program in 1999, and is currently employed as the GIS Supervisor for the City of San Luis Obispo, California. His practical experience using advanced GIS functions is passed on to NRM students through the classes Mr. Yun teaches at Cal Poly. Mr. Yun also provides extensive GIS consulting to both faculty and students' research projects. Mr. Yun’s unique position as a former student, current lecturer, GIS professional, and leading GIS consultant make him the ideal person to record and analyze 
NRM's GIS history, curriculum, and future direction. This scholarly project documents NRM’s GIS usage for research, management, and education. 


\section{CHAPTER 2}

What is GIS?

\section{Definition of GIS}

The definition of GIS is not an easy one to explain. There have been many attempts to write a formal definition that can be easily understood; however, we still struggle to grasp the essence of GIS and describe the nuances it encompasses. In fact, most GIS practitioners have a very difficult time explaining what they do. Often GIS practitioners resort to saying that they are "map makers.”

The following definitions are typically used for GIS education:

- An organized collection of computer hardware, software, geographic data, and personnel designed to efficiently capture, store, update, manipulate, analyze, and display all forms of geographically referenced information (ESRI, 1997a).

- A geographic information system, or geographical information system, is any system that captures, stores, analyzes, manages, and presents data that are linked to location (Wikipedia, 2010).

- A computer-based graphics program that allows the superposition of planmaps of thematic elements, such as roads, rivers, land use patterns, and the like to aid in local or regional planning activities (NOAA, 2010). 
GIS continues to evolve at a rapid rate as computer technology advances. The definition of GIS is also changing to incorporate broader applications. Nevertheless, the essence of GIS remains the same. Knowing the location information GIS provides was vital in the past, is essential today, and will be indispensable tomorrow. However, GIS is not just used for mapping locations or areas. It is also used to understand complex relationships between real world objects that are mapped. For example, a vegetation map should show what types of vegetation are growing in that area. A vegetation map overlaid with terrain (elevation, aspect, slope), soil and geologic, climate, and property information provides a better understanding of why certain vegetation is growing in a particular location. GIS is used to obtain more detailed information, discover new insights, and make better, more informed management decisions. GIS is a system used to manage, visualize, and analyze spatial information.

\section{Components of GIS}

There are five components in GIS: computer hardware, computer software, geographic data, personnel, and methods (ESRI, 1997b). The computer technology is one of the key components of GIS. GIS analyses requiring massive amounts of computation would be impossible without the use of computer hardware and associated software specifically designed for GIS functions. GIS software is written to recognize geographic features and their associated relationships. A geographic database links spatial information such as size, shape, and location with non-spatial attributes. GIS analyses require use of high-end computers with specialized software and data, and 
specifically trained personnel. Rules, guidelines, and standards are required to effectively use and manage GIS in any organization.

Although principles of GIS such as overlaying different layers for spatial analysis were discovered many years ago, practical application was usually tedious and difficult. Even when it was possible to draw different layers and overlay them, only small number of layers could be analyzed due to practical limitations. GIS with modern computers, specialized software, accurate data, and trained personnel who follow the established rules and standards has effectively eliminated past spatial analysis limitations.

\section{Types of Data}

In general, most GIS data is divided into two types: spatial and non-spatial. Spatial data contains information about locations or shape of geographic features and the relationship between them. In short, any data that can be mapped are considered spatial data. Non-spatial data is any data that does not have location qualities. For example, locations of buildings are spatial data while the type of building material is non-spatial data. A location of a tree is spatial data and the tree's species name is non-spatial data. In the realm of spatial data, most data is stored as either vector or raster data. Vector data stores geographic features in points, lines, and polygons. Typical geographic features stored in the vector data format have a discrete location or boundary such as fire hydrant, road, stream, lake, and city. Raster data stores geographic features in an array of equally sized cells arranged in rows and columns with one or multiple bands of values. Raster data is often used to store continuous data that does not have discrete boundaries such as temperature, elevation, and wind direction. 
The non-spatial data is often an attribute of spatial data. For example, a city is a spatial data, but the population size is not. People can easily understand where a particular tree is on a map but it would be very difficult to know the location of a tree based on an attribute such as tree height. However, most non-spatial data can be mapped by relating or joining it to spatial data. Although it would be difficult to locate a particular city based solely on population, we can easily show all potential cities that fall within a defined population size.

\section{Spatial Reference}

Spatial reference contains coordinate system, tolerance, and resolution of a spatial data layer. A coordinate system is a reference system that locates a position in space. It allows different spatial data layers to be placed in correct spaces and be spatially related to each other. There are many different types of coordinate systems. Two most broadly categorized coordinate systems are geographic coordinate system and projected coordinate system. Geographic coordinate system uses angular measurements (longitudes and latitudes) to locate the position on a sphere or spheroid. Projected coordinate system uses linear units of measurement on two or three dimensional surfaces as $\mathrm{X}, \mathrm{Y}$, and Z coordinates. Projected coordinate system depends on geographic coordinate system along with method of projection, and the unit of measurement. Most projected coordinate systems are identified by coordinate system name, zone, datum, and coordinate unit. Table 1 lists information about the four projected coordinate systems used at SPR and Valencia Creek Unit (VCU). 
Table 1

Commonly Used Projected Coordinate Systems in Swanton Pacific Ranch and Valencia Creek Unit

\begin{tabular}{|l|c|c|c|l|}
\hline Name & Zone & Datum & Unit & Notes \\
\hline $\begin{array}{l}\text { California State Plane } \\
\text { Coordinate System } \\
\text { (SPCS) }\end{array}$ & 3 & NAD83* & Feet & $\begin{array}{l}\text { Current coordinate system. County of } \\
\text { Santa Cruz and most local agencies use } \\
\text { this coordinate system. }\end{array}$ \\
\hline $\begin{array}{l}\text { California State Plane } \\
\text { Coordinate System } \\
\text { (SPCS) }\end{array}$ & 3 & NAD27 & Feet & $\begin{array}{l}\text { Old coordinate system. Most data in this } \\
\text { coordinate system was converted to } \\
\text { NAD83 datum. Some historical data } \\
\text { may be in this coordinate system. }\end{array}$ \\
\hline $\begin{array}{l}\text { Universal Transverse } \\
\text { Mercator (UTM) }\end{array}$ & 10 & NAD83 & Meter & $\begin{array}{l}\text { This coordinate system is typically used } \\
\text { by federal government agencies such as } \\
\text { USGS.** }\end{array}$ \\
\hline $\begin{array}{l}\text { Universal Transverse } \\
\text { Mercator (UTM) }\end{array}$ & 10 & NAD27 & Meter & $\begin{array}{l}\text { Old coordinate system. Most data in this } \\
\text { coordinate system was converted to } \\
\text { NAD83 datum. }\end{array}$ \\
\hline
\end{tabular}

*NAD stands for North American Datum

**USGS stands for United States Geological Survey

There are hundreds of projected coordinate systems; however, only some are applicable for a particular location. For example, California has 6 different State Plane Coordinate zones. Table 2 lists NRM’s most commonly used coordinate systems for San Luis Obispo area. 
Table 2

Commonly Used Projected Coordinate Systems in San Luis Obispo Area

\begin{tabular}{|l|c|c|c|l|}
\hline Name & Zone & Datum & Unit & Notes \\
\hline $\begin{array}{l}\text { California State Plane } \\
\text { Coordinate System } \\
\text { (SPCS) }\end{array}$ & 5 & NAD83 & Feet & $\begin{array}{l}\text { Current coordinate system. Most local } \\
\text { agencies use this coordinate system with } \\
\text { exception of the City of San Luis Obispo } \\
\text { which uses HARN (High Accuracy } \\
\text { Reference Network) datum. }\end{array}$ \\
\hline $\begin{array}{l}\text { California State Plane } \\
\text { Coordinate System } \\
\text { (SPCS) }\end{array}$ & 5 & NAD27 & Feet & $\begin{array}{l}\text { Old coordinate system. Most data in this } \\
\text { coordinate system was converted to } \\
\text { NAD83 datum. }\end{array}$ \\
\hline $\begin{array}{l}\text { Universal Transverse } \\
\text { Mercator (UTM) }\end{array}$ & 10 & NAD83 & Meter & $\begin{array}{l}\text { This coordinate system is typically used } \\
\text { by federal government agencies such as } \\
\text { USGS. }\end{array}$ \\
\hline $\begin{array}{l}\text { Universal Transverse } \\
\text { Mercator (UTM) }\end{array}$ & 10 & NAD27 & Meter & $\begin{array}{l}\text { Old coordinate system. Most data in this } \\
\text { coordinate system was converted to } \\
\text { NAD83 datum. }\end{array}$ \\
\hline
\end{tabular}

If layers have been developed using different geographic coordinate systems, a proper transformation method is required for layers to be integrated correctly. For example, if a layer designed in NAD27 needs to be placed on top of a layer designed in NAD83, then a transformation method from NAD27 to NAD83 must be applied for the layers to be placed in the correct locations.

Projected coordinate systems also have zones associated with specific geographic areas. Improper zone assignment could inadvertently place layers in the Pacific Ocean or in the Central Valley when they should be assigned to a completely different area. 


\section{Trends in GIS}

GIS technology, like computer technology in general, is evolving at a rapid rate. GIS began with a small group of dedicated individuals who had a passion for geography and a desire to use computer technology to map and analyze spatial data. Even in the 1990s, finding a GIS professional was not an easy task. Often, people from other disciplines became GIS professionals in order to do their jobs more efficiently. With advancements in computer technology and software development, GIS software, once the domain of a few select individuals, became a tool for everyone. Now, GIS software is running on virtually all devices that have any computing capability. A smart phone with a focused GIS application is becoming commonplace for everyday users.

\section{Hardware}

Computer technology is advancing at a rapid rate. In the past, GIS computer hardware was very expensive, and therefore, limited to the few companies or individuals who could afford it. Typically, companies using GIS would be government agencies, educational institutions, or large corporations. As the price of personal computers plummeted, they became attainable for the average industrialized household, and now are almost regarded as another regular household item such as a television or refrigerator. In fact, hardware technology has evolved to a point where handheld devices now effectively run GIS software. This trend will undoubtedly continue, and faster, smaller, and more affordable hardware should soon be available. 
Software

Computer software has evolved along with the hardware. Historically, individuals had to spend significant time learning a computer language to effectively use GIS; an endeavor most people preferred to avoid. The earliest versions of the GIS program ArcINFO were not easy applications to run. They required users to memorize many commands and be able to type series of command lines for analysis. It was similar to using DOS for early computers.

Data

The earliest form of geographic data was simple binary codes with limited information. Then came various forms of text files that represented geographic locations as well as values. From that humble beginning, GIS data has been developed into a complex data format that not only calculates the desired location but has a level of awareness of its surroundings and the rules associated with it. One of the popular GIS data formats was called coverages made for Environmental Systems Research Institute (ESRI)'s ARC/INFO application. Then came shapefiles with the more user-friendly ArcView application. Shapefiles are still the most widely used GIS data format. However, it is being replaced by geodatabase which came out with the new set of applications called ArcGIS Desktop. Geodatabase comes in a variety of types: personal geodatabase, file geodatabase, and enterprise geodatabase. Different types of geodatabase enable different functions. Table 3 shows information from ESRI's website comparing three different types of geodatabase (ArcGIS Resources Center, 2010). 
Table 3

Comparison of Different Geodatabases

\begin{tabular}{|c|c|c|c|}
\hline $\begin{array}{l}\text { Key } \\
\text { Characteristics }\end{array}$ & ArcSDE geodatabase & File geodatabase & Personal geodatabase \\
\hline Description & $\begin{array}{l}\text { A collection of various } \\
\text { types of GIS datasets held } \\
\text { as tables in a relational } \\
\text { database. (This is the } \\
\text { recommended native data } \\
\text { format for ArcGIS stored } \\
\text { and managed in a } \\
\text { relational database.) }\end{array}$ & $\begin{array}{l}\text { A collection of various } \\
\text { types of GIS datasets held } \\
\text { in a file system folder. } \\
\text { (This is the recommended } \\
\text { native data format for } \\
\text { ArcGIS stored and } \\
\text { managed in a file system } \\
\text { folder.) }\end{array}$ & $\begin{array}{l}\text { Original data format for } \\
\text { ArcGIS geodatabases } \\
\text { stored and managed in } \\
\text { Microsoft Access data } \\
\text { files. (This is limited in } \\
\text { size and tied to the } \\
\text { Windows operating } \\
\text { system.) }\end{array}$ \\
\hline $\begin{array}{l}\text { Number of } \\
\text { users }\end{array}$ & $\begin{array}{l}\text { Multiuser: many readers } \\
\text { and many writers }\end{array}$ & $\begin{array}{l}\text { Single user and small } \\
\text { workgroups: many readers } \\
\text { or one writer per feature } \\
\text { dataset, stand-alone feature } \\
\text { class, or table. Concurrent } \\
\text { use of any specific file } \\
\text { eventually degrades for } \\
\text { large numbers of readers. }\end{array}$ & $\begin{array}{l}\text { Single user and small } \\
\text { workgroups with smaller } \\
\text { datasets: some readers and } \\
\text { one writer. Concurrent use } \\
\text { eventually degrades for } \\
\text { large numbers of readers. }\end{array}$ \\
\hline Storage format & $\begin{array}{l}\text { - Oracle } \\
\text { - } \text { Microsoft SQL Server } \\
\text { - IBM DB2 } \\
\text { - IBM Informix } \\
\text { - PostgreSQL } \\
\end{array}$ & $\begin{array}{l}\text { Each dataset is a separate } \\
\text { file on disk. A file } \\
\text { geodatabase is a file folder } \\
\text { that holds its dataset files. }\end{array}$ & $\begin{array}{l}\text { All the contents in each } \\
\text { personal geodatabase are } \\
\text { held in a single Microsoft } \\
\text { Access file (.mdb). }\end{array}$ \\
\hline Size limits & Up to DBMS limits & $\begin{array}{l}\text { One TB for each dataset. } \\
\text { Each file geodatabase can } \\
\text { hold many datasets. The } 1 \\
\text { TB limit can be raised to } \\
256 \text { TB for extremely large } \\
\text { image datasets. Each } \\
\text { feature class can scale up } \\
\text { to hundreds of millions of } \\
\text { vector features per dataset. }\end{array}$ & $\begin{array}{l}\text { Two GB per Access } \\
\text { database. The effective } \\
\text { limit before performance } \\
\text { degrades is typically } \\
\text { between } 250 \text { and } 500 \mathrm{MB} \\
\text { per Access database file. }\end{array}$ \\
\hline $\begin{array}{l}\text { Versioning } \\
\text { support }\end{array}$ & $\begin{array}{l}\text { Fully supported across all } \\
\text { DBMSs; includes cross- } \\
\text { database replication, } \\
\text { updates using checkout } \\
\text { and check-in, and } \\
\text { historical archiving }\end{array}$ & $\begin{array}{l}\text { Only supported as a } \\
\text { geodatabase for clients } \\
\text { who post updates using } \\
\text { checkout and check-in and } \\
\text { as a client to which } \\
\text { updates can be sent using } \\
\text { one-way replication. }\end{array}$ & $\begin{array}{l}\text { Only supported as a } \\
\text { geodatabase for clients } \\
\text { who post updates using } \\
\text { checkout and check-in and } \\
\text { as a client to which } \\
\text { updates can be sent using } \\
\text { one-way replication. }\end{array}$ \\
\hline Platforms & $\begin{array}{l}\text { Windows, UNIX, Linux, } \\
\text { and direct connections to } \\
\text { DBMSs that can } \\
\text { potentially run on any } \\
\text { platform on the user's } \\
\text { local network }\end{array}$ & Cross-platform & Windows only \\
\hline
\end{tabular}


Table 3 (continued)

Comparison of Different Geodatabases

\begin{tabular}{|l|l|l|l|}
\hline $\begin{array}{l}\text { Key } \\
\text { Characteristics }\end{array}$ & \multicolumn{1}{|c|}{ ArcSDE geodatabase } & \multicolumn{1}{|c|}{ File geodatabase } & \multicolumn{1}{|c|}{ Personal geodatabase } \\
\hline $\begin{array}{l}\text { Security and } \\
\text { permissions }\end{array}$ & Provided by DBMS & $\begin{array}{l}\text { Operating file system } \\
\text { security }\end{array}$ & $\begin{array}{l}\text { Windows file system } \\
\text { security }\end{array}$ \\
\hline $\begin{array}{l}\text { Database } \\
\text { administration } \\
\text { tools }\end{array}$ & $\begin{array}{l}\text { Full DBMS functions for } \\
\text { backup, recovery, } \\
\text { replication, SQL support, } \\
\text { security, and so on }\end{array}$ & File system management & $\begin{array}{l}\text { Windows file system } \\
\text { management }\end{array}$ \\
\hline Notes & $\begin{array}{l}\text { Requires the use of } \\
\text { ArcSDE technology; } \\
\text { ArcSDE for SQL Server } \\
\text { Express included with } \\
\text { - ArcEditor and ArcInfo } \\
\text { - ArcGIS Engine } \\
\text { - ArcGIS Server } \\
\text { Workgroup } \\
\text { ArcSDE for all other } \\
\text { DBMSs included with } \\
\text { ArcGIS Server Enterprise }\end{array}$ & $\begin{array}{l}\text { You can optionally store } \\
\text { data in a read-only } \\
\text { compressed format to } \\
\text { reduce storage } \\
\text { requirements. }\end{array}$ & $\begin{array}{l}\text { Often used as an attribute } \\
\text { table manager (via } \\
\text { Microsoft Access). Users } \\
\text { like the string handling for } \\
\text { text attributes. }\end{array}$ \\
\hline
\end{tabular}

Geodatabase is the preferred data model for the ArcGIS Desktop application. It is simply a container for storing the geographic data. The latest trend shows that file geodatabase is replacing the shapefiles and personal geodatabase. The books Modeling Our World, The ESRI Guide to Geodatabase Design by Michael Zeiler (1999) and Designing Geodatabases, Case Studies in GIS Data Modeling by David Arctur and Michael Zeiler (2004) provide detailed information regarding geodatabase and its design concepts.

NRM's GIS database is currently stored in both shapefiles and file geodatabase formats. NRM does not currently use enterprise geodatabase. This is a significant investment as the cost of server hardware and software is well above $\$ 30,000$. 
Nevertheless, NRM has several staff members who are knowledgeable on the topic and can collaborate with other Cal Poly GIS interest groups to set up a university-wide spatial data server.

Personnel

Early GIS users needed extensive training to do the work. Often typing very long command lines, digitizing, and having to visualize the analysis required special training. As the software became easier to use, more and more people started to use GIS. Today, most of us use some sort of GIS software whether we realize it or not. Google Earth, Yahoo Maps, and other similar location and route searches use GIS technology. Many people are now able to effectively use GIS with minimal training. In the near future, knowing how to use GIS will become the norm, similar to how people currently use email programs to send messages or use Microsoft Word to create documents.

While the majority of people in industrialized countries will be using some form of GIS, there will still be a group of GIS professionals who will support the complex backend system. The trend suggests that GIS professionals will develop specific specializations, performing particular functions. Some will be become programmers who will create user-centric applications that can run on a variety of devices such as smart phones. There will also be GIS professionals focused on remote sensing, 3D analysis, and advanced spatial analysis. Some will continue traditional mapping and modeling. The Geographic Information System Certification Institute was created specifically to recognize and certify GIS professionals. 


\section{Standards}

Historically, there were no formal standards for early GIS professionals.

Practitioners and clients developed their own standards with very little concern for others. Sharing information was very difficult as most projects and practices were developed using unique standards in proprietary format. Quickly, GIS users along with government agencies realized that a formal GIS standard was required. One common GIS standard is using a predetermined coordinate system in lieu of making a custom coordinate system. Selecting the proper coordinate system for GIS data is very important. Prior to "projection-on-the-fly," in which software manages the alignment of two different coordinate systems, users had to manually convert coordinates in order to align the GIS layers. This created data duplication and confusion. GIS data could easily end up with several different coordinate systems, an inefficient use of manpower and resources. The worst case scenario is that the data might not end up having any coordinate system assigned. A user would have to literally guess what the coordinate system might be and test it by overlaying reference data. Unless the user was well aware of how the data was created, errors would be introduced in the process of assigning a coordinate system. In order to minimize this issue, organizations typically set an official coordinate system to be used for all projects. For example, Cal Poly’s GIS data is set to SPCS, California Zone 5, NAD 83, with units in feet. It is important to check the coordinate system at the beginning of each project. It is very possible for the same area to have different coordinate systems. The City of San Luis Obispo’s current official coordinate system is California State Plane Coordinate System, Zone 5, HARN NAD 83, with units in feet. 
The City of San Luis Obispo is using HARN datum which is the second generation of NAD 83, adjusted with Global Positioning System data to achieve higher accuracy. This enables the City to map features with a very high level of precision. Cal Poly chose their coordinate system because it is the standard used in several industries and gives students a working knowledge they can use right away as they start their careers. 


\section{CHAPTER 3}

GIS in Natural Resources Management

\section{Brief History of GIS in NRM}

According to Dr. Norman Pillsbury (personal communication 2004), GIS technology was first introduced to NRM in 1989 when he took the ESRI GIS training. The first NRM course was taught in 1990 with GIS software (ARC/INFO) running on their UNIX machine. Students would connect to the UNIX machines across campus via the Cal Poly Network from NRM’s computer lab. The following statement is from Dr. Norman Pillsbury regarding the beginning of NRM’s GIS program (personal communication, March 12, 2004).

“I taught the first GIS class at Cal Poly in spring 1990. It was upstairs in 11-304, which at that time was the Mac lab. We used the SE-20 Macintosh and some early version of ArcInfo (v. 1 ?). I just completed a series of five GIS classes at ESRI in Redlands, California, and being all fired up, came back to Cal Poly to teach the class. I think it was listed as an experimental class (probably FOR [Forestry] 470). I had about ten students in the class. Next, it was taught in summer 1990 as FOR 318 'Applications of GIS in Natural Resources.' I think I taught it a few times after that, but I really don’t remember much about the years between 1990 
and when Brian [Dietterick] started in 1994” (Dr. Norman Pillsbury,

Professor and Former Department Head, NRM, 2004).

Even though most people do not associate forestry programs with high end computer related technology, Dr. Pillsbury saw a value in GIS. Dr. Sarah Kocher taught GIS classes until Dr. Brian Dietterick was hired to lead NRM’s GIS program in 1994. Dr. Samantha Gill came to Cal Poly in 1997 and started to teach GIS classes. In 1997, David Yun's senior project was to incorporate the ArcView program into the GIS class. This was a milestone in NRM GIS history since it marked a shift in GIS application for the department. Prior to this, NRM was running the "command line" application on the remote UNIX server. It was difficult to learn because users had to memorize literally hundreds of commands and their syntax. Even when students learned the GIS application, they usually did not use it after graduation, as very few organizations had the ARC/INFO software. The new ArcView was a desktop application that ran on each machine with graphic user interface. Students no longer had to memorize long sequences of commands. Those tedious command line sequences were converted to a simple click of a button. A good analogy would be a personal computer operating system evolving from DOS to Windows. Prior to Windows, there were very few people who could effectively use computers since most people did not understand DOS commands. Windows opened the door for most people in industrialized countries to use personal computers. Likewise, ArcView allows many students to "play" with the software and learn GIS concepts and functions. In 1998, with encouragement from Drs. Dietterick and Pillsbury, David Yun was hired to teach GIS classes. Although NRM still maintained ARC/INFO software, Mr. Yun emphasized the use of ArcView each year. By the year 
2000, the department was no longer using the command line application. In 2001, NRM implemented ArcGIS Desktop which introduced additional applications such as ArcMap, ArcCatalog, ArcToolbox, and ArcScene. Prior to 2000, almost all GIS students were from NRM's Forestry and Natural Resources (FNR) major. After 2000, NRM observed that students from other majors such as Soil Science, Biology, Environmental Management, City and Regional Planning, and Civil Engineering started taking the class. In 2010, FNR majors comprised only a third of the class. NRM is the only department that offers at least one GIS class every quarter; therefore, the department has a significant influence on GIS education at Cal Poly. The scope of this scholarly project focuses on GIS usage in NRM only. Results cannot be generalized to other departments or the university as a whole.

\section{NRM GIS Database}

NRM's GIS database is organized by geography used by the department: SPR, Cal Poly, and VCU. Fairly large separation between the geographic areas made good sense to organize the data using geography. In most cases, GIS data is used for one specific area at a time. A person working on the Swanton Area does not need to go through VCU or Cal Poly data. Although department personnel combined all the GIS data into a master NRM GIS Database, it really is three distinct GIS databases. Each database has its own unique set of data. 


\section{Swanton}

The Swanton database has several gigabytes of data since most NRM projects are located in SPR. The original data was in coverage format that was based on USGS 7.5 minutes topographic maps or black and white, 1 meter resolution, quarter quadrangle aerials. In most cases the spatial accuracy was based on rough estimates at best. The current GIS layers are in shapefiles or file geodatabase format with all of the original data set updated with Light Detection and Ranging (LIDAR) information or 1 foot resolution color aerial images supplemented with Global Positioning System (GPS) data. The full list of Swanton GIS layers appears in Appendix D; however, the base layers are described in more detail below.

\section{SPR_Boundary}

A polygon delineating the Ranch Boundary.

Coverage spbound was originally created by J. Ramos using the Big Creek Lumber Company’s data. Then it was updated by S. Kocher and L. Eliassen in July 1992. Since July 1992, the Swanton boundary changed along Highway 1, at the junction of Mill Creek and Scotts Creek. The public land survey line, Scotts Creek, the Little Creek and the boundary line did not match. Corrections were made in these areas by David Yun in July 1997. The data was converted to shapefile in SPCS, California Zone 3, NAD83, with units in feet. Two other revisions followed in 2002 and 2007 using more precise information gathered from Santa Cruz County Assessor data, color aerial images, and LIDAR. 
SPR_Stream

A line depicting the centerline of streams in and near SPR.

The original coverage data was converted to shapefile in 1997 as part of a data conversion and update by David Yun and Mark Searby. In 2002 and 2007, data was updated using the LIDAR data. The key attributes are TYPE $(1=$ perennial, 2 = intermittent) and STR_CLASS (Stream class rating of 1, 2, or 3).

SPR_Road

A line depicting the centerline of the roads.

The original data was created from USGS 1:24000 Davenport and Año Nuevo transportation 2 DLG (Digital Line Graph) Quadrangles. In 1997, data was converted to shapefile and updated with newer DLG. A major update was made in 2002 with LIDAR data. In 2009, road data was updated too with even better LIDAR data and expanded beyond the immediate ranch boundary. The key attribute is RoadClass that has three attribute values: 1 = Highway 1, 2 = Paved Roads, and 3 = Unimproved Dirt Roads. The data prior to 2009 had an additional attribute value (4 = Railroads); however, the railroad attribute was separated into its own layer since characteristics of the railroad are vastly different from other roads. 


\section{SPR_Vegetation}

A polygon delineating the different vegetation types in SPR.

The original data source is from John Todd's report on Vegetation Type Map

of SPR in 1988. Since then the data was converted to shapefile and updated by David

Yun and Mark Searby in 1997. David Yun made more updates in 2003 using better aerial imagery.

Table 4

Attributes of SPR_Vegetation Layer

\begin{tabular}{|c|c|c|c|}
\hline \multicolumn{2}{|c|}{ Code is in the following order } & \multicolumn{2}{|c|}{ Example: RWDFSX4G } \\
\hline \multicolumn{2}{|c|}{$\begin{array}{l}\text { Primary Vegetation } \\
\text { Secondary Vegetation } \\
\text { Tertiary Vegetation } \\
\text { Average crown Diameter } \\
\text { Density }\end{array}$} & \multicolumn{2}{|c|}{$\begin{array}{l}\text { RW - Primary Vegetation } \\
\text { DF - Secondary Vegetation } \\
\text { SX - Tertiary Vegetation } \\
4 \text { - Average crown Diameter } \\
\text { G - Density }\end{array}$} \\
\hline Codes & Vegetation Types & Crown Diameter & Density \\
\hline $\begin{array}{l}\text { CL } \\
\text { DF } \\
\text { GX } \\
\text { HA } \\
\text { HX } \\
\text { MP } \\
\text { NB } \\
\text { NW } \\
\text { RW } \\
\text { SX }\end{array}$ & $\begin{array}{c}\text { Cultivated } \\
\text { Douglas-Fir } \\
\text { Grassland } \\
\text { Alder } \\
\text { Misc. Hardwood } \\
\text { Monterey Pine } \\
\text { Barren } \\
\text { Water, Wetlands } \\
\text { Redwood } \\
\text { Brushfield }\end{array}$ & $\begin{array}{c}3=13^{\prime}-24^{\prime} \\
4=25^{\prime}-40^{\prime} \\
5=\text { more than } 40^{\prime}\end{array}$ & $\begin{array}{c}\mathrm{P}=\text { less than } 40 \% \\
\mathrm{G}=\text { more than } 40 \%\end{array}$ \\
\hline
\end{tabular}


SPR_Soil

A polygon delineating different soil map units in SPR.

It is not clear how the original soil data was created; however, it appears that someone used a digitizing table to trace the soil map made by the Soil Conservation Service (now called Natural Resources Conservation Service) for Santa Cruz County. In 1997, a temporary intern, G. Farmer, updated the attribute table to join the most commonly used attributes to the feature. The attribute S_S is for shrink and swell of soil characteristics. The texture attribute value is percent composition of sand, silt, and clay. Table 5 shows detailed information about SPR_Soil. 
Table 5

Attributes of SPR_Soil

\begin{tabular}{|c|c|c|c|c|c|c|c|c|c|}
\hline $\begin{array}{l}\text { Map } \\
\text { unit }\end{array}$ & Soil name & $\begin{array}{c}\text { Slope } \\
\text { max-min }\end{array}$ & $\begin{array}{l}\text { Hydro } \\
\text { group }\end{array}$ & S_S & $\mathrm{K}$ factor & Depth & $\begin{array}{c}\text { A } \\
\text { depth }\end{array}$ & $\begin{array}{c}\text { B } \\
\text { depth }\end{array}$ & Texture \\
\hline 100 & Aptos loam, warm & 15-30 & $\mathrm{C}$ & $\bmod$ & 0.17 & 40 & 23 & 29 & 404020 \\
\hline 103 & Aquents, flooded & & & & & & & & \\
\hline 113 & $\begin{array}{l}\text { Ben Lomond-Catelli- } \\
\text { Sur complex }\end{array}$ & $30-75$ & B & low & 0.17 & 60 & 19 & 30 & 603010 \\
\hline 116 & Bonnydoon loam & $5-30$ & $\mathrm{D}$ & $\bmod$ & 0.32 & 20 & 11 & & 404020 \\
\hline 117 & Bonnydoon loam & $30-50$ & $\mathrm{D}$ & $\bmod$ & 0.32 & 20 & 11 & & 603010 \\
\hline 118 & $\begin{array}{l}\text { Bonnydoon-Rock } \\
\text { Outcrop complex }\end{array}$ & $50-85$ & $\mathrm{D}$ & mod & 0.32 & 20 & 11 & & 603010 \\
\hline 129 & Elder sandy loam & $0-2$ & B & low & 0.32 & 60 & 23 & & 603010 \\
\hline 130 & Elder sandy loam & $2-9$ & B & low & 0.32 & 60 & 23 & & 603010 \\
\hline 133 & Elkhorn sandy loam & $2-9$ & B & $\bmod$ & 0.28 & 60 & 21 & 61 & 404020 \\
\hline 138 & Felton sandy loam & $5-9$ & B & mod & 0.28 & 72 & 11 & 43 & 404020 \\
\hline 142 & Lompico-Felton & $5-30$ & B & mod & 0.17 & 72 & 5 & 37 & 404020 \\
\hline 146 & Los Osos loam & $5-15$ & $\mathrm{C}$ & high & 0.28 & 40 & 11 & 36 & 404020 \\
\hline 147 & Los Osos loam & $15-30$ & $\mathrm{C}$ & high & 0.28 & 40 & 11 & 36 & 404020 \\
\hline 148 & Los Osos loam & $30-50$ & $\mathrm{C}$ & high & 0.28 & 40 & 11 & 36 & 404020 \\
\hline 151 & Maymen stony loam & $30-75$ & D & mod & 0.24 & 20 & 6 & 14 & 404020 \\
\hline 153 & $\begin{array}{l}\text { Maymen-Rock } \\
\text { Outcrop complex }\end{array}$ & $50-75$ & $\mathrm{D}$ & mod & 0.24 & 20 & 6 & 14 & 404020 \\
\hline 159 & $\begin{array}{l}\text { Pfeiffer gravelly } \\
\text { sandy loam }\end{array}$ & $15-30$ & B & low & 0.17 & 66 & 24 & 53 & 603010 \\
\hline 160 & $\begin{array}{l}\text { Pfeiffer gravelly } \\
\text { sandy loam }\end{array}$ & $30-50$ & B & low & 0.17 & 66 & 24 & 53 & 603010 \\
\hline 167 & $\begin{array}{l}\text { Santa Lucia shaly } \\
\text { clay loam }\end{array}$ & $5-30$ & C & low & 0.1 & 40 & 38 & & 353530 \\
\hline 168 & $\begin{array}{l}\text { Santa Lucia shaly } \\
\text { clay loam }\end{array}$ & $30-50$ & $\mathrm{C}$ & low & 0.1 & 40 & 38 & & 353530 \\
\hline 169 & $\begin{array}{l}\text { Santa Lucia shaly } \\
\text { clay loam }\end{array}$ & $50-75$ & $\mathrm{C}$ & low & 0.1 & 40 & 38 & & 353530 \\
\hline 170 & Soquel loam & $0-2$ & $\mathrm{~B}$ & $\bmod$ & 0.28 & 60 & 21 & & 404020 \\
\hline 171 & Soquel loam & $2-9$ & $\mathrm{~B}$ & mod & 0.28 & 60 & 21 & & 404020 \\
\hline 174 & $\begin{array}{l}\text { Tierra-Watsonville } \\
\text { complex }\end{array}$ & $15-30$ & $\mathrm{D}$ & high & 0.28 & 60 & 16 & 38 & 603010 \\
\hline 175 & $\begin{array}{l}\text { Tierra-Watsonville } \\
\text { complex }\end{array}$ & $30-50$ & $\mathrm{D}$ & high & 0.28 & 60 & 16 & 38 & 603010 \\
\hline 177 & Watsonville loam & $2-15$ & $\mathrm{D}$ & high & 0.28 & 60 & 18 & 39 & 404020 \\
\hline 179 & $\begin{array}{l}\text { Watsonville loam, } \\
\text { thick surface }\end{array}$ & $2-15$ & $\mathrm{D}$ & high & 0.28 & 60 & 18 & 39 & 404020 \\
\hline
\end{tabular}

Page 23 
SPR_Landuse

A polygon delineating the different land use areas in SPR.

The original data was created by Beth Anderson in 1994 using 1989 aerial photographs. Since then it went through several revisions in 1998 and 2003 using better aerial images. There are five major types of land uses: crops, forest, range, structure areas, and natural areas. Each TYPE contains more detailed UNIT GROUP and each individual UNIT ID. 
Table 6

Land Use Types and Unit Groups

\begin{tabular}{|c|c|}
\hline \multicolumn{1}{|c|}{ Type } & \multicolumn{1}{c|}{ Unit Group } \\
\hline 1 Crops & $1=$ U Pick \\
& $2=$ Oat hay \\
3 & $=$ Organic \\
& $4=$ Non-cultivated Fields \\
\hline $2=$ Forest & $5=$ Little Creek \\
& $6=$ Satellite Units \\
& $7=$ Scotts Creek \\
& $8=$ General Smith Tree \\
\hline $3=$ Range & $9=$ Pasture \\
& $10=$ Range \\
& $11=$ Holding Areas \\
\hline $4=$ Structure Areas & $12=$ Al Smith/Educational Center \\
& $13=$ Red House $/$ Railroad \\
& $14=$ Barn Area/Green House \\
& $15=$ Employee Residences \\
& $16=$ Fire Station/Boy Scout \\
& $17=$ Other Residences \\
\hline $5=$ Natural Areas & $18=$ Brushland \\
& $19=$ Beach Area \\
& $20=$ Scott Creek Zone \\
\hline &
\end{tabular}


Table 7

Land Use Individual Units

\begin{tabular}{|c|c|c|}
\hline Unit ID & Name & Description \\
\hline 1 & Pozzi Ranch & Forest Management Unit \\
\hline 2 & Brushland & $\begin{array}{l}\text { Mainly oak woodland brushfields, some } \\
\text { conifers may be present }\end{array}$ \\
\hline 3 & Brushland & $\begin{array}{l}\text { Mainly oak woodland brushfields, some } \\
\text { conifers }\end{array}$ \\
\hline 4 & Willow Field & Grasslands presently leased \\
\hline 5 & Mill Creek Unit & Forest Management Unit \\
\hline 6 & Boy Scout Camp & Outdoor camp for Boy Scouts \\
\hline 7 & Squirrel Flat Field & Dryland crop field \\
\hline 8 & Schoolhouse Ridge & Grasslands presently leased \\
\hline 9 & Brushland & $\begin{array}{l}\text { Mainly oak woodland brushfields, some } \\
\text { conifers may be present }\end{array}$ \\
\hline 10 & General Smith Tree & Forest Management Unit with large trees \\
\hline 11 & Pozzi Field & Dryland crop field \\
\hline 12 & Little Creek Unit 2B & Forest Management Unit \\
\hline 13 & Schoolhouse Field & Dryland crop field \\
\hline 14 & Mill Creek Field & Dryland crop field \\
\hline 15 & Scotts Creek Unit & Forest Management Unit \\
\hline 16 & Northwest & Grazing pasture, fenced \\
\hline 17 & Hayfield & Fenced hayfield \\
\hline 18 & Little Creek Unit 2A & Forest Management Unit \\
\hline 19 & Pete Meyer’s Hay Barn & Barn \\
\hline 20 & Little Creek Unit 3 & Forest Management Unit \\
\hline 21 & Lockheed & Grazing pasture, partially fenced \\
\hline 22 & Brushland & $\begin{array}{l}\text { Mainly oak woodland brushfields, some } \\
\text { conifers may be present }\end{array}$ \\
\hline 23 & Little Creek Unit 1 & Forest Management Unit \\
\hline 24 & Brushland & $\begin{array}{l}\text { Mainly oak woodland brushfields, some } \\
\text { conifers may be present }\end{array}$ \\
\hline 25 & Little Creek Scout Camp & $\begin{array}{l}\text { Abandoned Scout Camp/Al Smith's Family } \\
\text { Cabins }\end{array}$ \\
\hline 26 & China Ladder & Grazing pasture, fenced \\
\hline 27 & Hay Barn & Grazing pasture, partially fenced \\
\hline
\end{tabular}


Table 7 (continued)

Land Use Individual Units

\begin{tabular}{|c|c|c|}
\hline Unit ID & Name & Description \\
\hline 28 & Staub Range & Grassland areas used for cow/calf operations \\
\hline 29 & Staub House & $\begin{array}{l}\text { Former Staub Ranch and Site of Faculty } \\
\text { Housing }\end{array}$ \\
\hline 30 & Brushland & $\begin{array}{l}\text { Mainly oak woodland brushfields, some } \\
\text { conifers may be present }\end{array}$ \\
\hline 31 & Educational Center & University lecture and lab facilities \\
\hline 32 & Swanton East & Forest Management Unit \\
\hline 33 & Beach Area & $\begin{array}{l}\text { Beach and dunes adjacent to fields and } \\
\text { brush, west of Highway } 1\end{array}$ \\
\hline 34 & Scotts Creek Estuary & Scotts Creek Riparian Zone \\
\hline 35 & Red House Area & $\begin{array}{l}\text { Red House, George’s House, Employee } \\
\text { residences, SP Railroad, BBQ Area, Offices }\end{array}$ \\
\hline 36 & Horse Pasture & $\begin{array}{l}\text { Small pasture southeast of Al Smith's Place } \\
\text { and Logging Camp Site }\end{array}$ \\
\hline 37 & Cowboy Shack & Small fenced pen in China Ladder \\
\hline 38 & Twin Water Troughs & Grazing pasture, fenced \\
\hline 39 & Holding Pen & Small fenced pen \\
\hline 40 & Holding Pasture & Fenced Holding area for cattle or horses \\
\hline 41 & Non-cultivated Field & Former crop field \\
\hline 42 & Ocean View & Grazing pasture, fenced \\
\hline 43 & Shipping Corrals & Corrals located in China Ladder \\
\hline 44 & Non-cultivated Field & Former crop field \\
\hline 45 & CDF Fire Station* & $\begin{array}{l}\text { California Department of Forestry and Fire } \\
\text { Protection Fire Station }\end{array}$ \\
\hline 46 & Archibald Creek Unit & Forest Management Unit \\
\hline 47 & Brushland & $\begin{array}{l}\text { Mainly oak woodland brushfields, some } \\
\text { conifers may be present }\end{array}$ \\
\hline 48 & CDF & Grasslands presently leased \\
\hline 49 & Brushland & $\begin{array}{l}\text { Mainly oak woodland brushfields, some } \\
\text { conifers may be present }\end{array}$ \\
\hline 50 & Las Trancas & $\begin{array}{l}\text { Employee residences and former Ag. labor } \\
\text { camp }\end{array}$ \\
\hline 51 & Upper Ford Field & Rotational crop field \\
\hline 52 & Las Trancas Field & Rotational crop field \\
\hline
\end{tabular}


Table 7 (continued)

Land Use Individual Units

\begin{tabular}{|c|c|c|}
\hline Unit ID & Name & Description \\
\hline 53 & Queseria Range & $\begin{array}{l}\text { Fencing along Swanton Road with brush } \\
\text { borders }\end{array}$ \\
\hline 54 & No Name Draw & Forest Management Unit \\
\hline 55 & Brushland & $\begin{array}{l}\text { Mainly oak woodland brushfields, some } \\
\text { conifers may be present }\end{array}$ \\
\hline 56 & Train Flat Field & Rotational crop field and Christmas Trees \\
\hline 57 & Scotts Pasture & Oathay \\
\hline 58 & Diversion Field & Rotational crop field \\
\hline 59 & Brushland & $\begin{array}{l}\text { Mainly oak woodland brushfields, some } \\
\text { conifers may be present }\end{array}$ \\
\hline 60 & Queseria Creek & Forest Management Unit \\
\hline 61 & Scotts Pasture & Oathay field \\
\hline 62 & Scotts Pasture & Rotational crop field \\
\hline 63 & Scotts Pasture & Grasslands presently not utilized \\
\hline 64 & Non-cultivated Field & Former crop field \\
\hline 65 & Strawberry Patch & Rotational crop field \\
\hline 66 & Dow Area & Pesticide experimental testing area \\
\hline 67 & Brushland & $\begin{array}{l}\text { Mainly oak woodland brushfields, some } \\
\text { conifers may be present }\end{array}$ \\
\hline 68 & Folger Field & Rotational crop field \\
\hline 69 & OK Corral & Fenced corral area \\
\hline 70 & Scotts Pasture & Rotational crop field \\
\hline 71 & Scotts Pasture & Oathay \\
\hline 72 & Long Barn Field & Rotational crop field \\
\hline 73 & Barn Area & Barn, Casa Verde, Bunkhouse \\
\hline 74 & Cheese House & Barn \\
\hline 75 & Scotts Creek Marsh & Marsh \\
\hline
\end{tabular}

* California Department of Forestry 
SPR_Topo

A line depicting contour lines in SPR.

The original data source was from USGS 1:24,000 scale topographic map. David Yun created more accurate contour lines using Spatial Analyst extension in ArcMap and LIDAR data.

SPR_Slope

A polygon delineating the different slope classes in SPR.

An attribute named SLOPECODE contains value that associates certain ranges of percent slope values. Slope data was created from the LIDAR derived DEM in 2002.

Table 8

Slopecode Definition

\begin{tabular}{|c|c|}
\hline Slopecode & Percent Slope \\
\hline 1 & $0-2$ \\
\hline 2 & $2-5$ \\
\hline 3 & $5-10$ \\
\hline 4 & $10-15$ \\
\hline 5 & $15-20$ \\
\hline 6 & $20-25$ \\
\hline 7 & $25-30$ \\
\hline 8 & $30-35$ \\
\hline 9 & $35-50$ \\
\hline 10 & $>50$ \\
\hline
\end{tabular}

Page 29 
Cal Poly

Cal Poly GIS data stored in NRM's GIS database is mainly supplemental data to Cal Poly Facilities’ GIS database. Its primary function is to provide quick access to frequently used GIS data for NRM students. It contains information such as aerial images of various years, Cal Poly ranch boundaries, student projects, etc. Additional Cal Poly data can be found at the City of San Luis Obispo and the County of San Luis Obispo government offices. The SLO DataFinder provides GIS data to anyone who has internet access. The Cal Poly network is also connected to a GIS server containing the extensive local data for campus faculty and students. The Cal Poly GIS data is located in Appendix D.

\section{Valencia Creek Unit}

VCU is managed by SPR staff as a forest management unit for demonstration and educational purposes. The VCU GIS data is very similar to Swanton GIS data in both organization and structure. Most data was created for management purposes for forest management and timber harvest activities. VCU GIS Data is located in Appendix D. 


\section{CHAPTER 4}

GIS for Research

NRM has used GIS technology on many research projects. It is safe to state that most projects after 1998 have included some type of GIS involvement. Several of the department’s notable GIS research projects are summarized below.

\section{Pitch Canker}

Several pitch canker research projects used GIS as the primary tool to plan and manage spatial data. Elicia Wise, Jason Pinkerton, Christina Brassey, and Valerie Loe completed their thesis reports using GIS technology. Without GIS technology, the work would have been difficult to manage or analyze. The experimental design (Appendix E) written by David Yun, Dr. Douglas Piirto, and Dr. Walter Mark became a basis for creating several original pitch canker GIS layers that eventually became working GIS data for Ms. Wise (2004), Mr. Pinkerton (2006), and Ms. Loe (2010). The original and latest GIS data layers related to the pitch canker projects are located in Appendix D. The creation of several key pitch canker GIS layers is described in the pages that follow. 


\section{Continuous Forest Inventory Data}

NRM's pitch canker project is primarily located on the western part of SPR between Scotts Creek and the rangeland. Continuous Forest Inventory (CFI) points were laid out by Steve Auten in 1999.

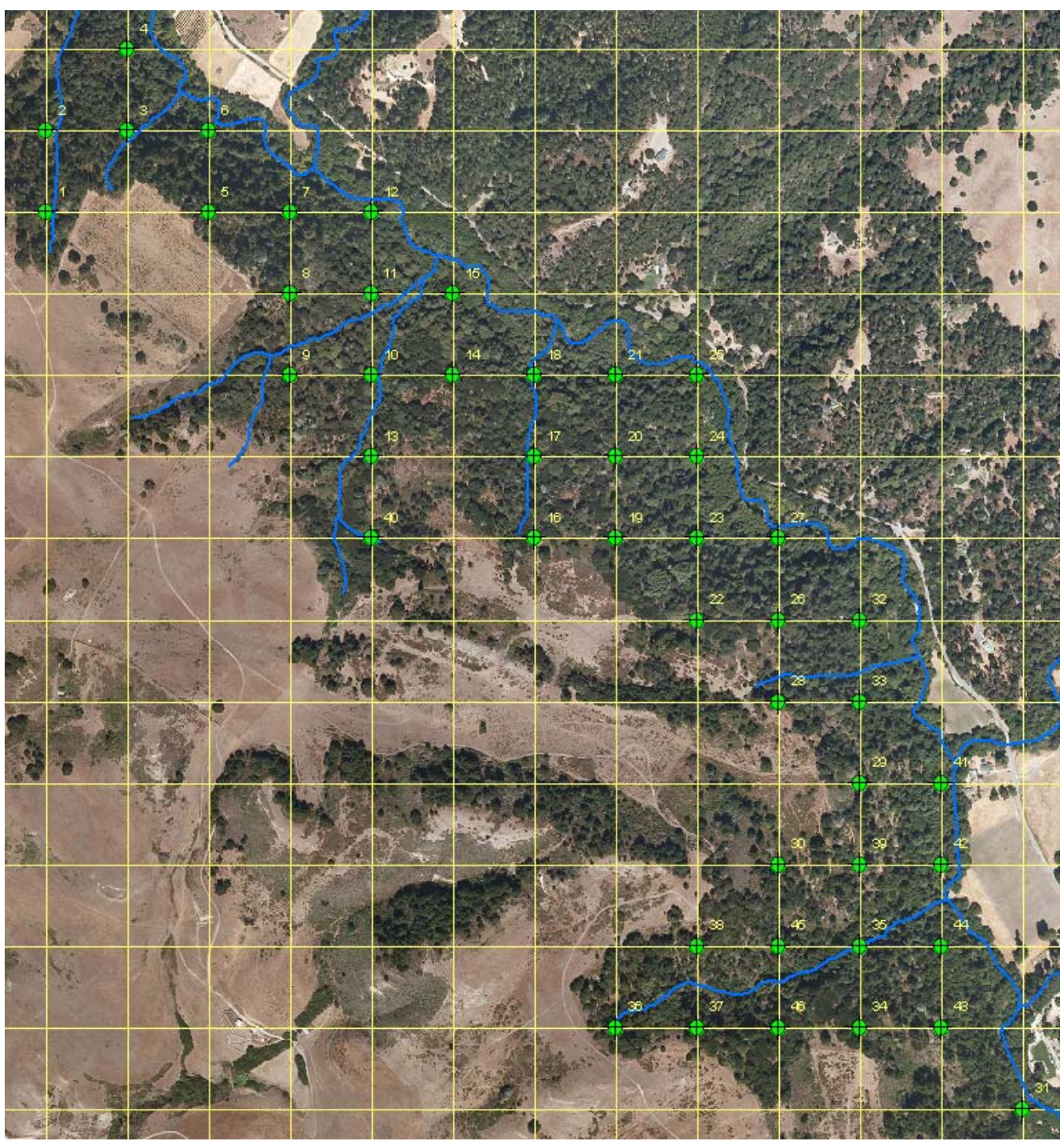

Fig. 1. Scotts Creek CFI Points. 
CFI points and CFI grids were created using GIS and GPS. Detailed information on determining the CFI points is written in Steve Auten's report, Continuous Forest Inventory for Swanton Pacific Ranch Scotts Creek Management Unit (Auten, 2000). The CFI points were used as the center of a 1/5 acre circular sample plot and all trees within the sample plot were surveyed. The survey crew collected bearing and distance of every tree along with all other tree specific attributes. The bearing and distance information was converted to X and Y coordinates. All trees with calculated X and Y coordinates were instantly mapped in GIS applications. Without the use of GIS, mapping would have taken a very long time, possibly even several months.

The key concept was using the sine and cosine functions. The CFI point coordinates were known since they had already been mapped in GIS. The bearing and distance to each tree was always from the CFI plot center. The origin of the Cartesian coordinate system was placed at the CFI point. A triangle was defined by the tree bearing angle and the tree distance (see Figure 2). The sine and cosine functions were used to calculate the opposite and adjacent sides which correlated to changes in $\mathrm{X}$ and $\mathrm{Y}$ values. The location of the tree, depending on which quadrant the tree was located in, determined whether opposite and adjacent values were added or subtracted from the CFI point's $\mathrm{X}$ and $\mathrm{Y}$ values to calculate the tree's $\mathrm{X}$ and $\mathrm{Y}$ coordinates. In Figure 2, the tree 1 (T1) coordinates were determined by adding the opposite value to CFI point's X value and adding the adjacent values to CFI point's Y value. The Tree 2 (T2) coordinate was determined by adding the opposite value to CFI point's X value and subtracting the adjacent value to CFI point's Y value. Figure 2 shows the formula for determining the tree’s coordinates for trees for all situations. 


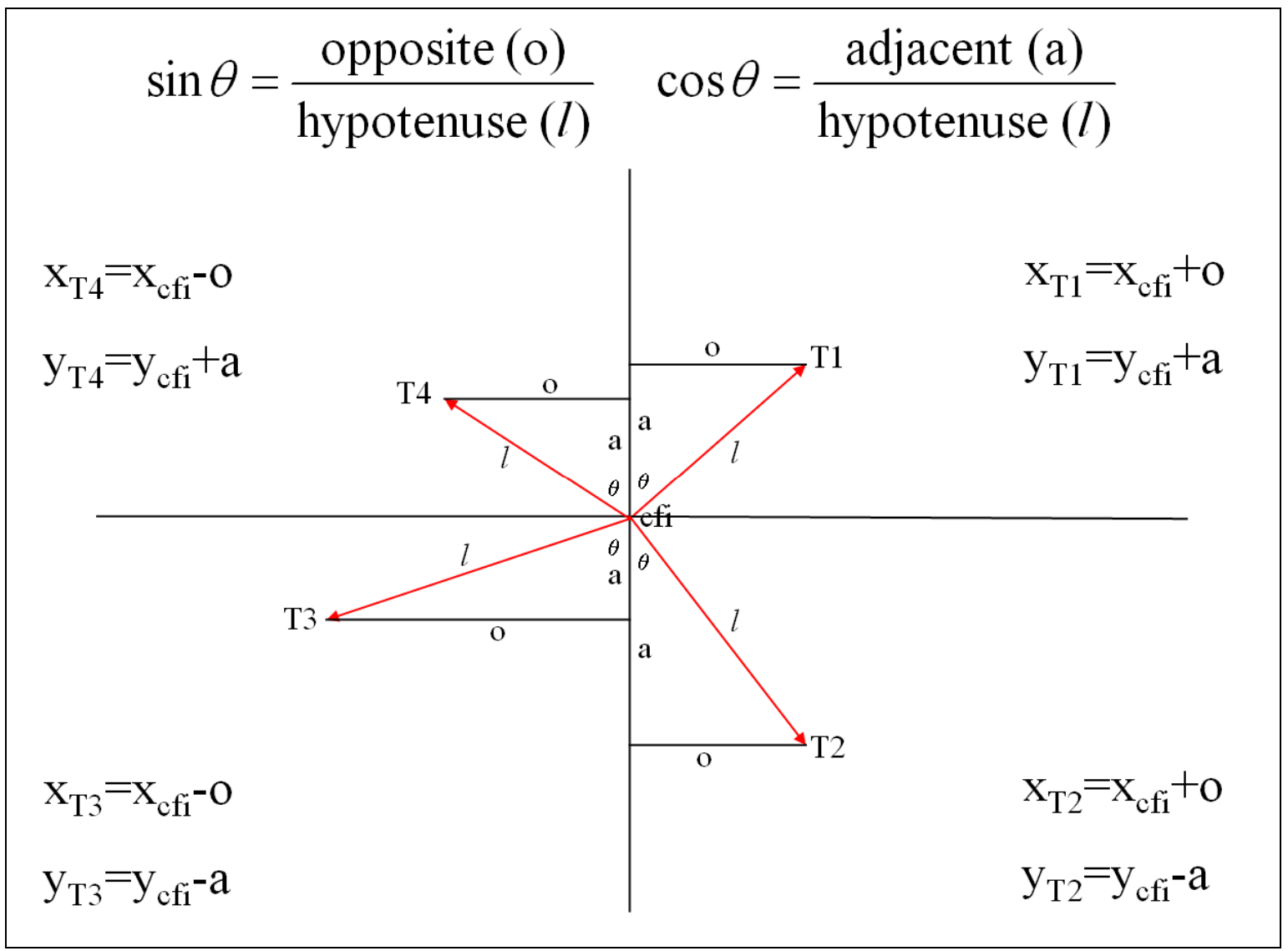

Fig. 2. Determining the Tree Coordinates.

Once surveyed trees’ coordinates were calculated, ArcView (currently replaced with ArcGIS Desktop) software was used to automatically create the survey tree GIS layer in less than a minute. The GIS software also transferred other tree attributes during the survey tree GIS layer creation process. Once in GIS layer, visualization and spatial analysis became a simple task.

Most people understand the sine and cosine function; however, few people know how to apply that learning to practical use. Mapping CFI points and survey trees demonstrates the practical application of mathematics and GIS technology. 


\section{Opening Design}

Group opening design for the pitch canker projects and site selection relied heavily on GIS technology. The research team mapped the Monterey pine (Pinus radiata) aggregate area to understand the size and shape of the project area. GIS software was used to create a template for group selection opening areas. Using the template, creating the group selection opening areas became as easy as "copy and paste.” A full description of the opening design is located in Appendix E.

\section{Seedling Planting Design}

Seedling planting design was also created in GIS. The detailed description of seedling planting design is documented in Elicia Wise’s thesis (2004). The key to success in mapping the seedlings was use of templates, snapping function in editing, and calculating the attributes automatically. Creating the template required a set of guide lines in 10 feet grid format. The template seedlings were positioned exactly 10 feet apart by snapping to the guidelines. Once the template was created, 2,280 seedlings were mapped accurately in under an hour. Each seedling was given a unique identification number that was used to join the external data. Common attribute information such as type of treatment and opening size were entered using "field calculator" in GIS to process all similar data at once. GIS enabled fast and accurate data entry. 


\section{Monterey Pine Growth and Yield Study}

Dr. Douglas D. Piirto and Dr. Sauli Valkonen (2005) studied structure and development of pitch canker (Fusarium circinatum) infected Monterey pine forest. The study was based on 17 sample plots in the Monterey pine aggregate areas. Their research found that the current Monterey pine stand was lacking natural regeneration and that management action was required to promote Monterey pines.

GIS was used to identify 17 sample plots based on Monterey pine aggregate areas. GIS was also used to plan for field data collection, mapping, and management of the database. GIS data and maps used for this study are located in Appendix D.

\section{Remote Sensing Project}

NRM's GIS Lab has earned a great deal of respect from other departments on campus and is often utilized for their research projects. Dr. James Keese from Cal Poly’s Geography Department, Thomas Mastin from the BioResource and Agricultural Engineering Department, and David Yun from NRM worked on a project using remote sensing technology to identify tropical montane forest on the eastern flank of the Andes Mountains in Ecuador. Land covers were identified using multispectral satellite imagery field data collection. GIS was used to analyze data to better understand relationships between the roads, slope, and deforestation as well as assessing potential conservation sites (Keese, 2007). The study was published in the Journal of Latin American Geography in 2007. A digital copy of the article is included in Appendix D. 


\section{CHAPTER 5}

GIS for Management

When it comes to resource management, GIS is the obvious choice for mapping and analyzing. Dr. Roger Tomlinson, "the father of GIS,” helped develop and used GIS to map the natural resources of Canada (Tomlinson, 2003). Management of resources without knowing location information is not practical. Would a forester be successful if he or she does not know what kinds of trees are located where? Foresters need to know much more than where trees are located. Terrain information such as steepness, solar radiation aspect, soil types, climate, hydrologic features, man-made features, jurisdiction lines, hazardous locations, and other information is required for effective resource management. This chapter describes a land use mapping project demonstrating the use of GIS for ranch management.

\section{Land Use Map Project}

NRM has maintained and enhanced the SPR Land Use Map as new information became available. The land use map is typically used for management purposes. A properly designed land use map is very useful for planning projects, identifying locations, communicating during meetings, and many other purposes. In 2008, ESRI announced the Mapping Forestry publication project. Mr. Yun designed the SPR Land Use Map and authored a brief article describing how the map was made; both were submitted and 
accepted for publication. A description of the Mapping Forestry book from ESRI's website (ESRI, 2010) is provided below:

Mapping Forestry offers a look at current and cutting-edge approaches to forestry from around the world and describes how GIS software supports the business of forestry in today's era of economic changes, increased global competition, and diminishing resources. In real scenarios from the United States, Canada, Bolivia, Brazil, Cambodia, Finland, and Romania, foresters share how they use GIS to manage commercial operations and maintain sustainable stewardship. Forest managers describe how computer-generated maps and GIS analysis help them make important decisions about the best places to build roads, whether logging in a particular area is commercially feasible, and which fire-damaged areas should be restored first. This book contains 19 chapters, each with a full-color map, featuring detailed descriptions of the types of GIS analysis that it represents. Mapping Forestry is the definitive GIS guide for forestry professionals (ESRI, 2010). 


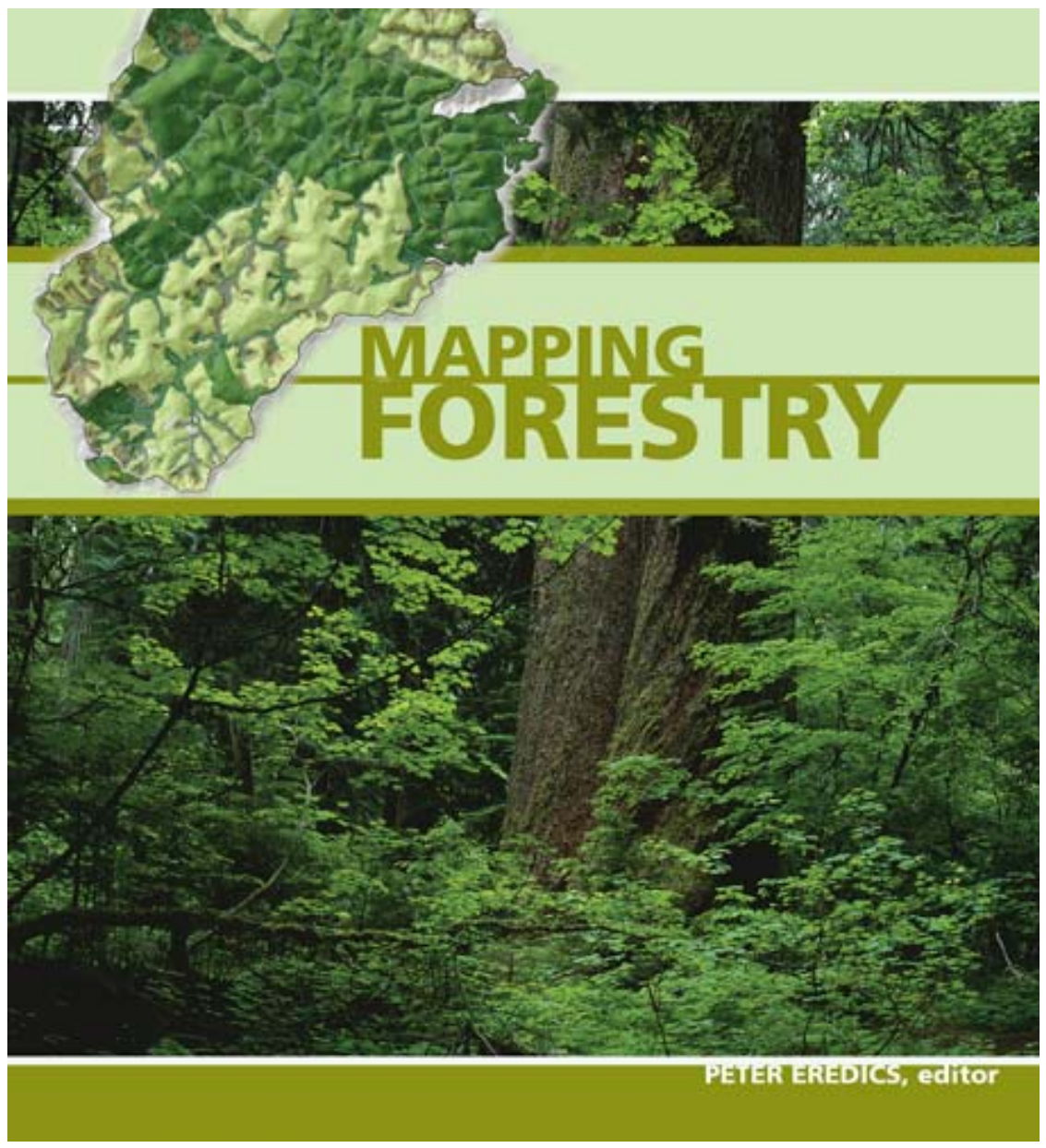

Fig. 3. Mapping Forestry Cover Page. (ESRI, 2010)

The SPR Land Use Map is featured in Chapter 12 of Mapping Forestry. A full text of the submitted article is located in Appendix B.

\section{Mapping Infrastructure}

GIS is often used to map and manage infrastructure features such as communication conduits, water and sewer pipes, electric lines, and other buried assets. NRM used GPS to collect feature locations to obtain better spatial accuracy. Knowing 
the exact location is vital for mapping and managing the underground infrastructure. If location is uncertain, large areas are disturbed to find the feature, but if an asset is mapped accurately, only small areas are disturbed. This difference in mapping accuracy usually translates into significant time and resource allocations. Appendix D contains some of the underground infrastructure. 


\section{CHAPTER 6}

GIS for Education

\section{GIS Courses}

NRM was strongly committed to GIS education from the beginning. Even today, NRM is the only department that consistently offers several GIS classes every quarter at Cal Poly. It is clear that NRM has a very significant influence on GIS education at Cal Poly. Many GIS professionals working for the County of San Luis Obispo have been educated in NRM's GIS classes. There are three GIS specific classes offered by NRM. Descriptions for these classes are taken from the Cal Poly course catalog.

NR 317: The World of Spatial Data and Geographic Information Technology Basic foundation for understanding the world through geographic information and tools available to utilize spatial data. Application of Geographic Information Systems (GIS) and related technologies, including their scientific basis of operation. Not open to students with credit in NR 318. 3 lectures, 1 activity. Prerequisite: Junior standing, a course in computer science, and completion of Area B. Cross listed as GEOG/LA/NR 317. Fulfills GE Area F. 


\section{NR 318: Applications of GIS}

ARC/INFO and ArcView Geographic Information System (GIS) computer software to explore environmental, natural resource, social and economic issues using spatial data. Develop and apply data base and software management competencies. 1 lecture, 2 laboratories. Prerequisite: Junior standing, computer literacy or consent of instructor. Cross listed as LA/NR 318. Basic Skills of GIS.

\section{NR 418: Applied GIS}

Acquisition, organization and analysis of spatial data from diverse sources using Geographic Information System (GIS) software. GIS modeling applications and validation techniques used in development and preparation of client-driven projects. 1 lecture, 2 activities. Prerequisite: NR/LA 318.

NRM mainly offered the NR 418 class for those who wished to earn a GIS minor; however, the popularity of the class attracted many others who were simply interested in learning more about GIS. The essence of NR 418 is to apply what students learned in NR 318 by working on a real GIS project. Unlike NR 318, where data is prepared for students and all exercises are designed to be completed in the same fashion by each student, NR 418 projects require students to do unique work on real world projects. Simply, NR 418 is applying the learned GIS knowledge to a real project (in Cal Poly's learn-by-doing tradition). 


\section{Project Examples}

Several notable projects were accomplished through the NR 418 class. Several projects were presented at the International ESRI User Conference, published as maps and technical reports. Several examples follow.

\section{Chamber of Commerce Mapping}

The San Luis Obispo Chamber of Commerce needed a new street map that they could use on their visitor's map. The previous maps were copyrighted by a private graphic designer who would not allow the Chamber to duplicate the map. The Chamber of Commerce is a non-profit organization that serves the community. A map created by students in NR 418 is still being used by the San Luis Obispo Chamber of Commerce. The map is located in Appendix D.

\section{Important Bird Areas (IBA) Mapping}

The main objective of the Important Bird Areas project was delineating the bird habitat area using descriptive location information. Although the concept was simple, the actual work required many hours to investigate and delineate the site. A more detailed description is located in Appendix C. This project was presented at the International ESRI User Conference and was publicized in several online articles. A technical report, Mapping California’s Important Bird Areas, was published by the Audubon California in 2008. 


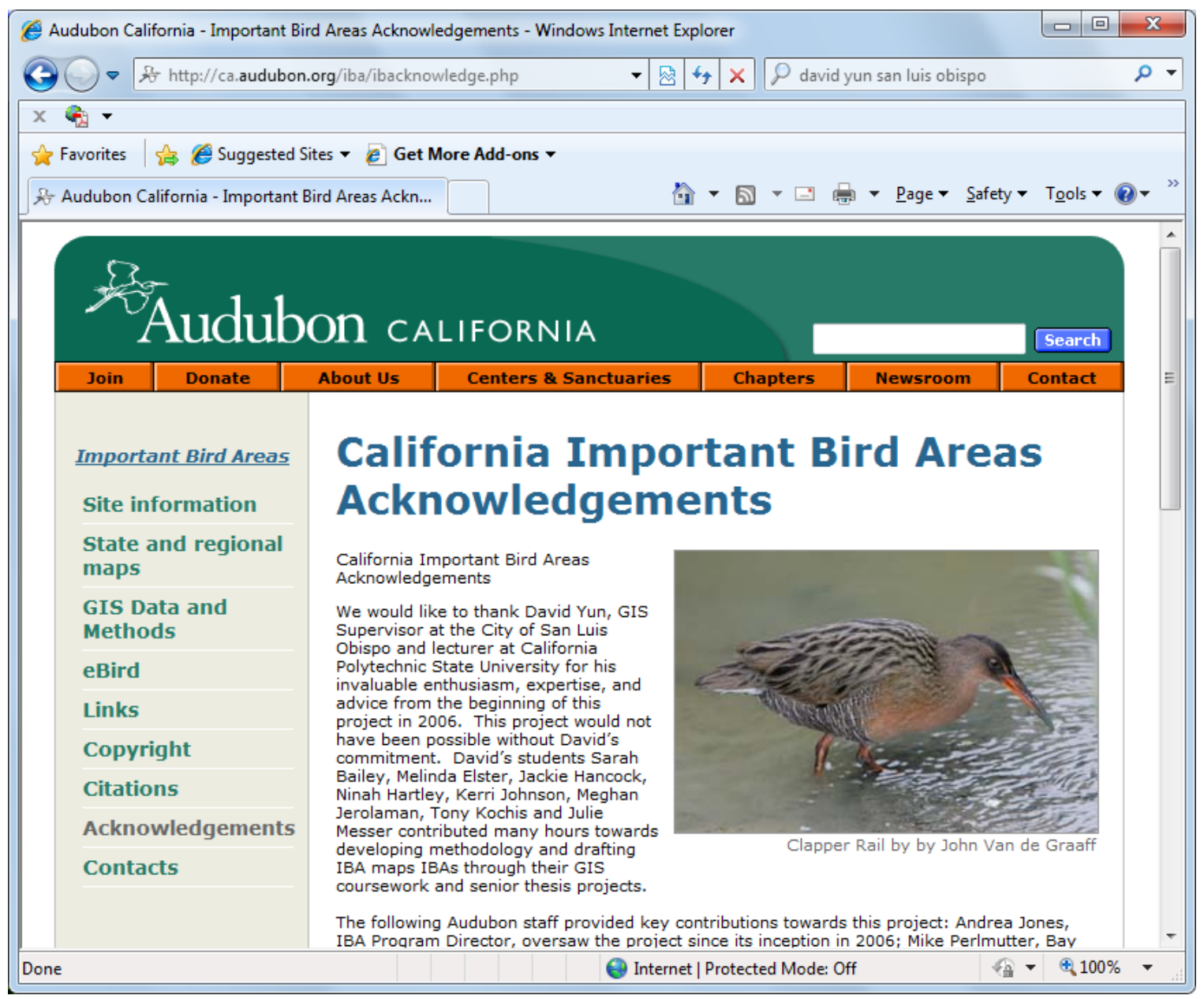

Fig. 4. Screen Capture of the Audubon California IBA Acknowledgement. (Audubon California, 2008)

\section{Mapping Oblique Photos of Hillsides}

The residents of San Luis Obispo, California are very protective of the hills surrounding the city. In order to protect the treasured views of the hills, a base line information of hillside views was needed. A helicopter was chartered with a professional photographer who took photographs of all of the hills. The photographs had time stamps. A GPS device collected each position. GPS data was converted to a GIS point layer with time. The photos were linked to the GPS point layer using the 
time stamp. This allowed users to quickly access the correct hillside image by simply clicking on the point. This project was presented at the International ESRI User Conference in 2009 (Yun, 2009). 


\section{CHAPTER 7}

Conclusions and Recommendations

GIS has evolved very rapidly over the last few decades. NRM is keeping up with the latest GIS technology by staying current on software upgrades. NRM leads GIS education at Cal Poly by offering more GIS classes than any other department. Faculty and students are using GIS effectively on their research and course projects. SPR staff are using GIS to manage the ranch’s 3,200 acres. Many dedicated individuals collaborated to make NRM’s GIS program successful.

Although NRM is doing an excellent job with its GIS program, the following recommendations are given to further improve the program:

1. Write a strategic plan for NRM's GIS Program. GIS is rapidly evolving. A strategic plan with a vision and goals will help guide NRM’s GIS Program, even through tough budget years.

2. Revise the course title and descriptions for NR 318. A better course title would be "Introduction to GIS." NRM no longer uses ARC/INFO and ArcView. The description should reflect what is being taught in the course. The course really is an introduction to GIS.

3. Explore and expand the use of GIS on mobile devices. Anyone involved in field data collecting should take either an ArcPad or an ArcGIS Mobile class. Using the field GIS application will expedite the data collection process with less errors 
than using field notes. NRM faculty and students will greatly benefit by using the mobile GIS devices.

4. Explore the "GIS in Cloud" option. The term "GIS in Cloud" means that the data and application are all stored on the internet. Practitioners could then be anywhere and do GIS work as long as they have internet access. This trend of “computing in the cloud” is creating a lot of industry "buzz." Both ESRI, the leading GIS software maker in the world, and Amazon.com are preparing to make “GIS in the Cloud” readily available to consumers.

5. Establish a GIS advising service enabling faculty and students with a central location to ask GIS questions on research projects. GIS is a very powerful tool that saves time and reveals spatial relationships between objects that would be difficult to detect without the use of GIS. A good GIS consultation at the beginning of the project will save days or even months of work, as well as better understand how to use GIS technology.

GIS is an exciting, innovative field of study. Its applications in research, management, and education are growing exponentially as its usability and affordability make it more accessible to users worldwide. NRM's daunting challenge is to keep abreast of the rapid advances in the field and communicate the ever-growing possibilities to tomorrow's industry leaders through relevant, cutting-edge courses. One of NRM's advantages is that its advanced GIS courses are already designed to teach students how to apply GIS technology to real-world projects; helping students get a head-start at solving the kinds of problems they are likely to face in their careers. Another advantage is that 
NRM hires industry professionals to teach courses. These professionals bring the latest research and software applications into the classroom and once again, students can directly relate to how GIS can be used in their chosen fields. Students also have the opportunity to apply their learning to projects at several Cal Poly locations: the extensive San Luis Obispo campus, the College of Agriculture’s 3,200 acre SPR which runs an active forestry program, and VCU, as well as opportunities in the local community.

Future applications for research include bringing GIS technology to a personal level by developing applications that are portable, affordable, and extremely userfriendly. Opportunities abound for professionals in the field who are interested in developing and managing these resources. GIS is definitely a growing discipline. NRM is in the unique position of trying to anticipate the future needs of GIS professionals by providing the educational tools they will use to meet growing demand. Meeting the challenge will be difficult, but ultimately rewarding. The future of GIS is bright and NRM is poised to lead future industry leaders "into the light." 


\section{Literature Cited}

ArcGIS Resources Center. (2010). Retrieved December 3, 2010, from http://help.arcgis.com/en/arcgisdesktop/10.0/help/index.html\#/

Types_of_geodatabases/003n00000007000000/

Arctur, D. and M. Zeiler. (2004). Designing Geodatabases, Case Studies in GIS Data Modeling. Redlands, CA: ESRI Press.

Audubon California. (2008). Retrieved December 3, 2010, from http://ca.audubon.org/iba/ibacknowledge.php

Auten, Steve R. (2000). Continuous Forest Inventory for Swanton Pacific Ranch Scotts Creek Management Unit. Unpublished manuscript, Swanton Pacific Ranch. Davenport, California.

ESRI. (1997a). Understanding GIS, The ARC/INFO Method, Redlands, CA: ESRI Press.

ESRI. (1997b). Retrieved December 3, 2010, from http://www.gisday.com/cd2009/posters/5pointsofgis.pdf

ESRI. (2010). Retrieved December 3, 2010, from http://esripress.esri.com/display/index.cfm?fuseaction=display\&websiteID=168

Keese, J., Mastin, T. \& Yun, D. (2007). Identifying and assessing tropical montane forests on the eastern flanks of the Ecuadorian Andes. Journal of Latin American Geography, 6 (1), 63-84. 
Loe, V. (2010). Management strategies for pitch canker infected Año Nuevo stands of Monterey pine: a thesis. Unpublished Master’s thesis, California Polytechnic State University, San Luis Obispo, CA.

NOAA 2010. Accessed 3 Dec. 2010; available from http://www.nws.noaa.gov/glossary/index.php?letter=g

Pinkerton, J. (2006). Silvicultural management strategies for pitch canker infected Año/Nuevo stands of Monterey pine: second years gap regeneration results: a thesis. Unpublished Master’s thesis, California Polytechnic State University, San Luis Obispo, CA.

Tomlinson, R. (2003). Thinking About GIS, Geographic Information System Planning for Managers, Redlands, CA: ESRI Press,

Piirto, D.D. \& Valkonen, S. (2005). Structure and Development of Pitch Canker Infected Monterey Pine Stands at Año Nuevo, California. Forest Ecology and Management 213, $160-174$.

Wikipedia. (2010). Retrieved December 3, 2010, from http://en.wikipedia.org/wiki/Geographic_information_system

Wise, E. (2004). Silvicultural management strategies for pitch canker infected Año Nuevo stands of Monterey pine: first year gap regeneration results. Unpublished Master's thesis, California Polytechnic State University, San Luis Obispo, CA.

Yun. (2009). Retrieved December 3, 2010, from http://training.esri.com/campus/library/bibliography/RecordDetail.cfm?ID=89126 \&browseonly $=0$ 
Zeiler, M. (1999). Modeling Our World, The ESRI Guide to Geodatabase Design, Redlands, CA: ESRI Press. 


\section{Appendices}
A. List of ESRI User Conference Presentations
B. Mapping Forestry
C. Mapping California’s Important Bird Areas
D. DVD of NRM GIS Database and Digital Documents
E. Experimental Design 


\title{
APPENDIX A
}

\author{
List of ESRI User Conference Presentations
}

From 2002 to 2009, eight presentations were made at the ESRI User Conference.

2002: Impermeable Surface Analysis Using IKONOS Satellite Image

2003: Housing Development Suitability Model

2004: Decision Making Aided by 3D Scene

Monitoring Pine Pitch Canker with GIS

2005: Advanced GIS Course Designed to Provide Community Services

2006: Sports Complex Management Using GIS

2008: Mapping and Managing the Important Bird Areas with GIS

2009: Hillside Conservation Using GIS 


\title{
Impermeable Surface Analysis Using IKONOS Satellite Image
}

authored by David Yun, 2002

Proceedings of the Twenty-Second Annual ESRI User Conference

\begin{abstract}
In preparation of National Pollutant Discharge Elimination System (NPDES), the City of San Luis Obispo, California performed impermeable surface analysis with IKONOS multi-spectral satellite image using ERDAS IMAGINE, ArcGIS 8.1, and ArcView 3.2a. Vegetated areas are delineated using NDVI modeling. Combination of supervised and unsupervised classifications determined impermeable areas. City limit area is divided into various land use types, and they are overlaid with impermeable data. Percent impermeable areas are calculated for each land use types. Results are field checked.
\end{abstract}

Reference Type: Conference Proceedings

Conference Location: San Diego, CA

Publisher: ESRI

Author Affiliation: City of San Luis Obispo, Public Works, San Luis Obispo, CA, USA URL: http://training.esri.com/campus/library/bibliography/RecordDetail.cfm?ID=21655 \&browseonly $=0$ 


\title{
Housing Development Suitability Model
}

authored by David In Yun, 2003

Proceedings of the Twenty-Third Annual ESRI User Conference

\begin{abstract}
To minimize urban sprawl into surrounding scenic hills and peaks, the model was created to determine potential housing development sites within the City of San Luis Obispo’s urban reserve boundary. SIC code, land use, and parcel data were used to determine initial potential sites. LIDAR data was used to create slope grid to determine high slope area. Geology, hydrology, and hazard data were incorporated in the model to determine final potential sites. About 7 percent of lands within the urban reserve line are suitable for housing development. ESRI's ArcGIS with ArcGIS Spatial Analyst and 3D Analyst extensions were used for analysis.
\end{abstract}

Reference Type: Conference Proceedings

Conference Location: San Diego, CA

Publisher: ESRI

Author Affiliation: City of San Luis Obispo, Public Works, San Luis Obispo, CA, USA URL: http://training.esri.com/campus/library/bibliography/RecordDetail.cfm?ID=29005 \&browseonly $=0$ 


\title{
Decision Making Aided by 3D Scene
}

authored by David In Yun, 2004

Proceedings of the Twenty-Fourth Annual ESRI User Conference

\begin{abstract}
The City of San Luis Obispo council members had to decide whether to put a 50-foot flag pole on a hill located near the entrance of the city. One group advocated the project to display the flag as a patriotic symbol. Another group opposed the project to save the visual aesthetic of surrounding open space hills. ArcGIS was used to simulate the proposed flag pole in ArcScene. Aerial photograph was draped on top of the elevation grid. Point feature was put in the proposed location then extruded 50 feet to simulate the flag pole. 3D scene animations were captured as a movie clip for public hearing presentation. Spatial analysis was also used to delineate the areas that can and cannot see the flag pole. ArcGIS with 3D Analyst and ArcGIS Spatial Analyst extensions aided council members to come to a decision.
\end{abstract}

Reference Type: Conference Proceedings

Conference Location: San Diego, CA

Publisher: ESRI

Author Affiliation: City of San Luis Obispo, Public Works, San Luis Obispo, CA, USA URL: http://training.esri.com/campus/library/bibliography/RecordDetail.cfm?ID=33641 \&browseonly $=0$ 


\title{
Monitoring Pine Pitch Canker with GIS
}

authored by David In Yun, Douglas Piirto, Walter Mark, 2004

Proceedings of the Twenty-Fourth Annual ESRI User Conference

\begin{abstract}
Pitch canker is a disease caused by a fungus (Fusarium circinatum) in most coniferous tree species. Several pitch canker research projects were performed on Monterey pine (Pinus radiata) stand at Swanton Pacific Ranch, Davenport, California. GIS was used to map various survey transects, sampling plots, individual sample trees, and planted seedlings. ArcGIS allowed various data in different coordinate system, datum, and units to be managed easily. Using ArcGIS, an Excel spreadsheet, and simple trigonometry, most of the collected data were either mapped directly or linked to existing GIS layers. Although statistical analysis was done on Minitab, displaying the pitch canker activities were all done in ArcGIS Desktop and ArcView 3.3. Pitch canker rating data collected from 1999 to 2001 implied that there is a decrease in pitch canker activity at the study site. Showing the map that supports statistical analysis results had a great impact in the research presentation.
\end{abstract}

Reference Type: Conference Proceedings

Conference Location: San Diego, CA

Publisher: ESRI

Author Affiliation: City of San Luis Obispo, Public Works, San Luis Obispo, CA, USA URL: http://training.esri.com/campus/library/bibliography/RecordDetail.cfm?ID=33822 \&browseonly $=0$ 


\title{
Advanced GIS Course Designed to Provide Community Services
}

authored by David Yun, 2005

Proceedings of the Twenty-Fifth Annual ESRI User Conference

\begin{abstract}
Natural Resources Management Department at California Polytechnic State University-San Luis Obispo is offering an advanced GIS course (FNR 418-Applied GIS) that is designed to provide community services to university, local governments, state and federal agencies, and non-profit organizations. GIS students work on "real” projects that community organizations are not able to pursue due to lack of budget, time, personnel, or technical skill. These client-driven projects offer very valuable experiences of networking with organization leaders, developing and executing project plans, and providing community services. Students often have high expectations knowing that their project is helping the community. This is a "win-win" situation in that communities receive free services and students learn valuable lessons by experiencing the "real" project as well as promoting community service awareness.
\end{abstract}

Reference Type: Conference Proceedings

Conference Location: San Diego, CA

Publisher: ESRI

Author Affiliation: City of San Luis Obispo, Public Works, San Luis Obispo, CA, USA URL: http://training.esri.com/campus/library/bibliography/RecordDetail.cfm?ID=37052 \&browseonly $=0$ 


\title{
Sports Complex Management Using GIS
}

authored by David In Yun, 2006

Proceedings of the Twenty-Sixth Annual ESRI User Conference

\begin{abstract}
The city of San Luis Obispo built a new sports complex to meet growing demand for playing fields. The proposed site for a new sports complex had many challenges including road and creek realignment. Existing and proposed road realignment needed new elevation information. Realigned creeks needed wetland mitigation plan that required detailed assessment of the creek and its surroundings. GIS with GPS was used to create new elevation data for road realignment, assess creek realignment; calculate wetland areas; locate more than 2,000 newly planted vegetation; and make a wetland mitigation plan map. GIS was also used to plan for field layout as well as actual lining of the fields by using survey grade GPS. Today, the sports complex is being enjoyed by the citizens of San Luis Obispo.
\end{abstract}

Reference Type: Conference Proceedings

Conference Location: San Diego, CA

Publisher: ESRI

Author Affiliation: City of San Luis Obispo, Public Works, San Luis Obispo, CA, USA URL: http://training.esri.com/campus/library/bibliography/RecordDetail.cfm?ID=83442 \&browseonly $=0$ 


\title{
Mapping and Managing the Important Bird Areas with GIS
}

authored by David In Yun, Andrea Jones, Julie Messer, 2008

Proceedings of the Twenty-Eighth Annual ESRI User Conference

\begin{abstract}
Important Bird Areas (IBA) Program was created to identify and conserve sites that are vital to birds and other biodiversity. In California, 148 IBAs were identified; however, these sites were mapped as a point layer. Although point layer gives general location, it does not provide simple information such as size and shape. Audubon and Natural Resources Management Department at California Polytechnic State University joined efforts to create a polygon layer of IBA sites using ArcMap and other GIS programs. Using the site descriptions, aerials, topographic maps, and other resources, all IBA sites were mapped as a polygon feature class in a geodatabase. Maps created with IBA sites as a polygon layer provided more clear communication between different organizations. Land ownership and vegetation distribution analysis were performed for each IBA sites providing important management information. Newly created GIS data is also used by eBird online application.
\end{abstract}

Reference Type: Conference Proceedings

Conference Location: San Diego, CA

Publisher: ESRI

Author Affiliation: City of San Luis Obispo, San Luis Obispo, California, USA

URL: http://training.esri.com/campus/library/bibliography/RecordDetail.cfm?ID=82072 \&browseonly $=0$ 


\title{
Hillside Conservation Using GIS
}

authored by David In Yun, 2009

Proceedings of the Twenty-Ninth Annual ESRI User Conference

\begin{abstract}
The City of San Luis Obispo is surrounded by beautiful hillsides that are highly revered by its citizens. However, several development proposals were made that would change the hillside landscape from a natural to an urban setting. The citizens of San Luis Obispo made clear message to preserve the hillsides in natural setting. The GIS technology was chosen to plan and manage for developments near hillsides. In an effort to create the base record for hillside views, the City captured oblique aerial photographs of all hillsides from a low flying helicopter. GPS was used to locate the camera's position for each image. Photo points layer with a link to images was overlaid with other base layers such as zoning, parcels, addresses, and elevation to quickly access and relate all relevant information. GIS enabled City planners to make better planning decisions and allowed them to communicate more effectively.
\end{abstract}

Reference Type: Conference Proceedings

Conference Location: San Diego, CA

Publisher: ESRI

Author Affiliation: City of San Luis Obispo, San Luis Obispo, CA, USA

URL: http://training.esri.com/campus/library/bibliography/RecordDetail.cfm?ID=89126 \&browseonly $=0$ 


\section{APPENDIX B}

\section{Mapping Forestry}

In 2008, Peter Eredics, ESRI Forestry Manager, asked NRM to submit materials for ESRI’s new Mapping Forestry book. It was ESRI’s first forestry specific mapping book and showcased NRM’s GIS/Mapping capability. In August of 2008, all required materials were submitted and accepted. In 2010, the book was finally published. Chapter 12 (Mapping Land Use at Swanton Pacific Ranch) contains NRM’s submittals which are appended below. 


\title{
Mapping Land Use at Swanton Pacific Ranch
}

\author{
David Yun \\ Lecturer/GIS Specialist \\ Natural Resources Management Department \\ California Polytechnic State University \\ 1 Grand Avenue \\ San Luis Obispo, CA 93407 \\ dyun@calpoly.edu \\ phone: (805) 781-7189 \\ fax: (805) 781-7198
}

Page 63 


\section{Section Title}

Mapping Land Use at Swanton Pacific Ranch

\section{Map and Project Description}

Swanton Pacific Ranch is a 3,200-acre educational and research facility owned by Cal Poly Corporation in the coastal mountains north of Santa Cruz, California. The ranch contains many different landscapes: forest, range, crop land, wetland, and many developed areas with structures. The variety of landscapes provides excellent opportunities for many different educational projects. The ranch was donated by the late Al Smith who wanted the ranch to be maintained as a working ranch and used exclusively for agriculture, recreational, and educational purposes. California Polytechnic State University’s College of Agriculture, Food and Environmental Sciences runs SPR like a commercial ranching operation, with crops, grazing, and forestry programs. The ranch provides a unique environment to foster interdisciplinary "learning by doing” about sustainable resource management. Faculty and graduate students actively pursue research opportunities in the ranch's forest, range, and watershed areas.

The entire ranch is divided into five major land use types that correspond to different landscapes. There are three main ranch operations: forestry, livestock, and crops. The forested lands are predominantly second-growth redwood and Douglas fir forests with some Monterey pines on the coastal side of the forest. Most trees were heavily logged in the early 1900s in order to replenish 
timber needs to rebuild San Francisco after the earthquake and fire. Regular logging activities continued through the 1970s. Forestry is still the predominant operation at SPR. Livestock operation occurs in the range land located on the ocean side of the ranch that overlooks the Pacific Ocean. Typical livestock operations are stocker, cow-calf, and sheep. Crop land located in the southern part of the ranch grows organic vegetables. Wetlands and other natural areas provide excellent educational tours for students and many visitors. Structured areas consist of houses, barns, shed, and any other built structures in the ranch. All five major land use types are further divided into management units. Management units are determined by their location and usage. For example, a range land use type consists of several holding areas and pastures by location. There are a total of 75 management units.

The various land uses and operations draw many people to the ranch. Many interns stay several months on the ranch. Students visit the ranch regularly for a variety of class projects. Graduate students and faculty members perform many research projects at the ranch. The ranch is also used as a meeting and demonstration place for visitors from educational institutions or governmental agencies. With so many different people visiting the ranch, a map showing all administrative boundaries in detail with other reference information such as roads and streams was needed. NRM's GIS Specialist created a map showing the management units, which helps ranch managers more efficiently manage projects and communicate with others; it is much easier to show the map than to describe the units in words. The map serves as the base map for many projects at the 
ranch. An example of this is the overlay of Little Creek Watershed project on top of the land use map. 
A Visual Solution (describe what we see on the map and visually analyze the map-what do we learn from the map? How is the map used successfully? What solutions and benefits does the map provide? How did the design help to make the point?)—Character limit: 2,825

SPR is divided into 75 land management units. These management units are grouped into five land use types. The management units are identified by unit ID number and boundary lines. The land use types are delineated with thicker transparent lines with unique colors for each land use type. Roads are separated into highway, paved roads, and dirt roads. Streams are shown as either perennial or intermittent.

The CFI points are used as referenced points for many activities such as mapping forest lands, selecting sampling trees, and inventory of trees. These points are re-bars driven into the ground with a yellow cap and metal identification tags. They are placed in a 500 feet square grid pattern.

The parcel layer provides legal property boundaries in the ranch. It is shown with assessor's parcel numbers to clearly identify and show the locations of each parcel.

ArcGIS online resources were used to create the overview map. This is available for a fee at the ESRI Resource Center. At the time of the map’s creation, the GIS Specialist used the ArcGIS Online beta site to access the data.

The aerial image was originally purchased from AirPhotoUSA (now Digital Globe) in 2005 to help identify and create GIS layers for land surface 
features. It is extensively used as background imagery for many projects at the ranch.

LIDAR data originally purchased for the watershed study was used to create the elevation grid and the hillshade raster. Although it is used to show the terrain in this map, LIDAR data can be used to detect many land surface features such as forest roads that are hidden by trees, landslide deposits, hazardous slopes, and more.

With the exception of ArcGIS Online Services, the aerial image, and the LIDAR data, all other data was created by Cal Poly students who had their senior project in the ranch or who were enrolled in the Advanced GIS class. The ranch managers and GIS specialist reviewed the data several times before using it as a base GIS layer.

In addition to features, several well known geographic locations are annotated for quick reference.

The map designed for ANSI C (17 x 22 inches) can be used as either a wall map or a working field map. The wall map is an excellent way of communicating with visitors regarding project locations. The map is also used as a base map that users can quickly modify to showcase their specific projects.

It is a multipurpose map that can be used by many people to communicate clearly regarding land uses in the ranch. 


\section{Resource Tables}

Table B-1

Data Dictionary

\begin{tabular}{|l|l|}
\hline \multicolumn{1}{|c|}{ General Data Description } & \multicolumn{1}{c|}{ Sources (Where can you find similar data?) } \\
\hline 2005 Aerial Image & Digital Globe \\
\hline Parcels & Digitized using Assessor's map \\
\hline Roads & $\begin{array}{l}\text { Digitized using Aerial and LIDAR data. Local } \\
\text { government may have many roads mapped; } \\
\text { however many ranch roads are usually not mapped. }\end{array}$ \\
\hline Streams & Digitized using Aerial and LIDAR data \\
\hline Land Use & $\begin{array}{l}\text { Created by ranch managers. } \\
\text { This is Swanton Pacific Ranch specific land use data. }\end{array}$ \\
\hline Continuous Forest Inventory & Created from survey information \\
\hline ESRI_ShadedRelief_World-2D & ArcGIS Online Resources \\
\hline LIDAR Data & Acquired for watershed research project \\
\hline
\end{tabular}

Table B-2

Software Dictionary

\begin{tabular}{|l|l|}
\hline \multicolumn{1}{|c|}{ Software } & \multicolumn{1}{c|}{ Description } \\
\hline ArcInfo 9.2 & $\begin{array}{l}\text { Creating and updating all layers } \\
\text { Creating the map }\end{array}$ \\
\hline Spatial Analyst & $\begin{array}{l}\text { To create the elevation grid and the hillshade } \\
\text { raster layer }\end{array}$ \\
\hline
\end{tabular}


Table B-3

Additional Resources

\begin{tabular}{|l|c|}
\hline \multicolumn{1}{|c|}{ Resource } & \multicolumn{1}{c|}{ Description and Source } \\
\hline Trimble 4800 GPS & For collecting survey data for CFI establishment \\
\hline Compass & For collecting data where GPS does not work \\
\hline
\end{tabular}

\section{Full-Page Graphic of the Maps}

Author: David Yun

Organization: Natural Resources Management Department, California Polytechnic State

University, San Luis Obispo.

\section{How to build this map}

To create a similar land-use map, follow these steps:

- Conduct a meeting with ranch managers to identify what features to put on the map. Explain (or demonstrate) that putting every available layer on a map is not feasible. Determine set of desired layers for map.

- Determine available layers and what additional layers are needed. County and local government may have many data layers that are needed for the project. Obtain all necessary layers. In our case, we had many students creating the data and GIS Specialist checking the data.

- Edit any layers that need adjustment. Spatial accuracy requirements are different for many layers that are produced by other agencies. Update all layers to your accuracy standard.

- Organize layers for proper display. Display land use and parcel layers as hollow fill to allow the aerial image to show through. Other point and line features are symbolized so that they can be seen clearly and distinctively. Experiment with several colors as it is difficult to pick a color that will work well in all areas since aerial image is used as background. 
- In order to achieve the better cartographic effect of showing the boundaries with a semi-transparent border, a separate land use type layer was created. Creating the hollow center and making thick boundaries for the land use types allows much of the background information to show through while providing clear boundary delineation. While most professional cartographers use Adobe Illustrator to create visually pleasing maps, we decided to use the ArcGIS Desktop only for map making so that many students trained in GIS could update and modify the map. It is not common to find people who are proficient in Adobe Illustrator.

- Use transparency to show multiple layers. In this case the aerials are visible under the thick land use type layer boundary.

- Create a balanced look by placing the map elements using align and distribute tools.

- Use scale units and divisions that makes sense. Set the scale bar division values to a well rounded number. For example, if the default scale is divided into 1105 meters, values should be changed to 1000 meters for a cleaner look.

- For a finishing touch, customize the map with logo, signs, brands, or other graphics to make your map stand out from others. In this case "lazy S P," which is the ranch's branding image, is placed at top of the map and built into a north arrow.

\section{Conclusion}

Ranch managers want to have their land mapped accurately with detail. With so many people visiting the ranch, showing locations within the ranch is a very common task. The map clearly shows all possible land use units that everyone can identify. Any confusion regarding site location is eliminated by using the map. By showing the parcel, land use types, and land use units, most management planning can be accomplished using the map. The aerial image further supports more specific locations as users can easily identify features such as barns, shacks, boulders, pools, fences, brush, trails, etc. 
SPR's mission is to demonstrate and teach informed stewardship of the land and this land use map helps ranch managers to accomplish this goal. The map shows complete land use information and has plenty of room for other project layers to be added. The multi-purpose capability sets this map apart from other similar maps.

\section{Keywords}

Land Use, Landuse, management, Parcel, operational, management, units, planning, base map.

\section{Contact Information}

David Yun

Lecturer

Natural Resources Management Department

California Polytechnic State University

1 Grand Ave

San Luis Obispo, CA 93407

dyun@calpoly.edu

Voice: 805-781-7189

Fax: 805-781-7198

Digital submittals including the SPR Land Use Map are located in Appendix D. 


\section{APPENDIX C}

Mapping California’s Important Bird Areas

Mapping California’s Important Bird Areas project was one of the most publicized NR 418 projects. In 2006, Andrea Jones, Director of the Important Bird Areas Program at Audubon California, approached me to take on the project as a part of student learning. Audubon California did not have staff, time, and GIS knowledge to take on the project. The objective was to convert the location description in the book (Important Bird Areas of California) to GIS data. While the concept was simple, the actual work was very difficult. The entire project lasted two years from 2006 to 2008 with a total of seven students working on it. In 2008, the technical report from Audubon California was written in order to help other states to do similar work. This project was presented at the International ESRI User Conference in 2008. The project is also featured in several online articles.

GeoInformatics Website: http://www.geoinformatic.org/archives/837

Cal Poly Website: http://calpolynews.calpoly.edu/news_releases/2009/March/birds.html

ESRI Press Release: http://www.esri.com/news/releases/09_1qtr/california_bird_habitat.html

GIS and Science http://gisandscience.com/2009/03/23/gis-helps-california-audubon-identifyessential-bird-habitat/ 


\section{APPENDIX D}

DVD of NRM GIS Database and Digital Documents

The DVD includes the following:

- Geodatabase for SPR, VCU, and Cal Poly areas

- Digital orthophotos of SPR, VCU, and Cal Poly areas

- Archived historical GIS data

- Digital copy of published documents mentioned in this scholarly project report.

- Digital copy of maps for NRM

- Digital copy of GIS professional certificate 


\section{APPENDIX E}

Experimental Design

\section{Monterey Pine Pitch Canker Group Selection Study Experimental Design by David Yun, Dr. Douglas Piirto, and Dr. Walter Mark}

The original conception of designing the group selection opening relied heavily on use of GIS for determining the opening locations and creating the graphic materials to convey the message. Although actual implementation changed the number of repetitions from four to three, other design specifications were followed. 


\title{
Monterey Pine Pitch Canker Group Selection Study Experimental Design
}

by

\author{
David Yun, Dr. Douglas Piirto and Dr. Walter Mark
}

Pitch canker is a tree disease caused by fungus (Fusarium circinatum). Monterey pine (Pinus radiata) is one of the species that is highly susceptible to pitch canker. Currently most Monterey pine stands are diseased with pitch canker, and there is very little regeneration occurring due to very dense stand structure. Our study is to promote regeneration of Monterey pine using silvicultural treatments.

\section{Shape of opening:}

Shape of opening will be a circle to minimize biased (aspect) edge effect.

\section{Size of openings:}

The radius of circular opening is measured from center to the canopy drip line. Three different opening sizes will be considered in order to see the effect of gap sizes.

- 1/2-acre opening: largest opening allowed for our area.

- 1/4-acre opening: mid-size opening to make gradual transition from $1 / 8$ acre opening to $1 / 2$-acre opening.

- 1/8-acre opening: small opening in the forest. Anything smaller would be too small for real management application in forest settings. This also ties in with the University of California, Berkeley study at Monterey Peninsula. 


\section{Treatments:}

Many treatments that were considered in the beginning (e.g., prescribed burning, mechanical/chemical treatment, lop and scatter slash outside of group cut, chipping/mulching) were dropped due to either lack of available resources or having to conform to local state forest practice rules. For example, local state forest practice rules prohibit the use of prescribed burning as a site preparation treatment in Santa Cruz County. As such only two treatments will be tested:

- Lop and scatter--one of the common practices done in our study area. Lop and scatter all logging debris below 12 inches high and less than 6 feet long.

- Tractor pile and burn--pile debris to center of plot then burn.

The control areas will have no action done to them. No trees will be cut in the control units. This will enable us to compare the extent of pitch canker resistant Monterey pine regeneration in uncut mature forest areas as contrasted to created group selection openings.

\section{Random location of openings:}

Center point for each opening will be randomly selected from all potential points that could serve as the center point. The coordinate system used for locating the center point is a UTM coordinate system in Zone 10 with NAD 1927. Opening sizes and treatments are also randomly chosen for each selected center point. If the randomly selected opening can be established in the Monterey pine stand then use it; otherwise, return the center point coordinates into a drawing pool and pick again until the circular 
opening can be established (meaning physically fit within the Monterey pine aggregate area and have 100 feet buffer from each other). It is possible for a particular coordinate to be used for a small opening but not the large one due to physical limitations. Physical limitations include lack of land available at the site as well as rough terrain (small, deep

gully). Once selected, the center of the opening will be marked with permanent marking (galvanized steel pipe with location stamped on cap). Steel pipe will be driven into ground at least 2 feet and have 1 foot above ground for easy location.

\section{Number of openings:}

Since control areas will not be harvested, the actual openings are eight $1 / 2$-acre openings, eight 1/4-acre openings, and eight 1/18-acre openings. A total of 7 acres will be treated and 3.5 acres will serve as control areas. 


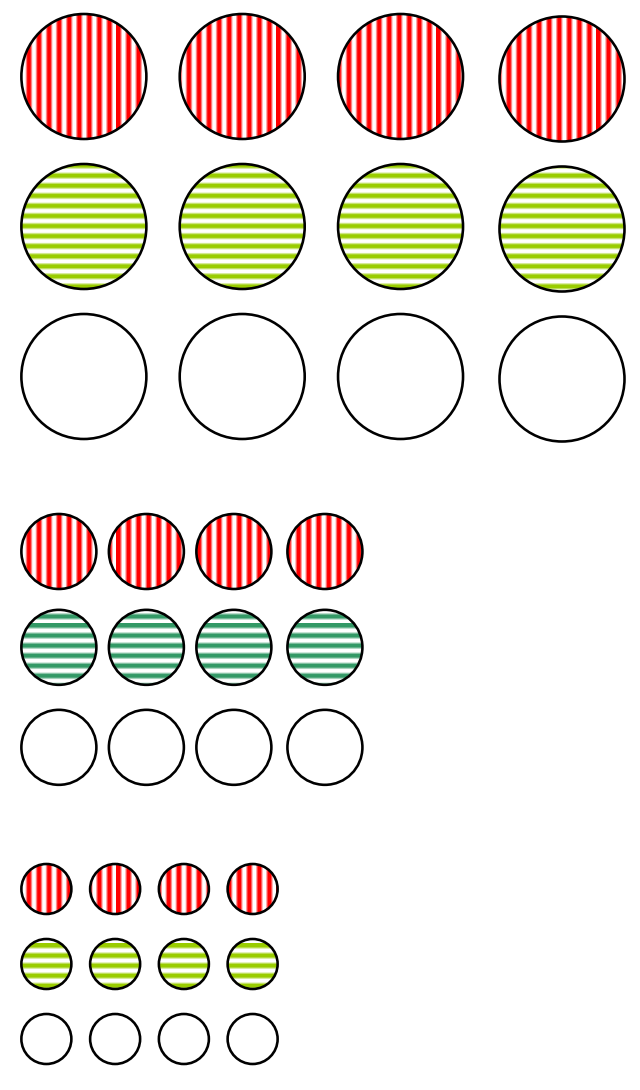

4 (1/2-acre) Pile and burn: debris burned 4 (1/2-acre) Lop and scatter: debris on ground 4 (1/2-acre) Control: No cutting/treatments $1 / 2$-acre $=21780 \mathrm{ft}^{2}=0.2023 \mathrm{ha}$, Radius $=83.26$ feet

4 (1/4-acre) Pile and burn: debris burned 4 (1/4-acre) Lop and scatter: debris on ground 4 (1/4-acre) Control: No cutting/treatments 1/4-acre $=10890 \mathrm{ft}^{2}=0.1012 \mathrm{ha}$, Radius $=58.87$ feet

4 (1/8 acre) Pile and burn: debris burned 4 (1/8 acre) Lop and scatter: debris on ground. 4 (1/8 acre) Control: No cutting/treatments $1 / 8$ acre $=5445 \mathrm{ft}^{2}=0.0506 \mathrm{ha}$, Radius $=41.63$ feet

Fig. E-1. Group Opening and Treatment Design.

\section{Seeds and Seedlings:}

Two source seeds will be collected: cones from pitch canker resistant and nonresistant (according to the inoculation test result). The Pitch Canker resistance test was performed by CDF and the University of California. Resistance is evaluated as lesion length that developed after pitch canker inoculation. For our experimental design, the tree with average lesion length of $<3.5 \mathrm{~mm}$ is considered to be resistant and the tree with 
average lesion length of $>3.5 \mathrm{~mm}$ is considered to be non-resistant. The reason for planting two sources of Monterey pine is to determine any significant difference in seedling survival and growth from resistant versus non-resistant trees.

Seeds will be prepared for germination and sowed one year prior to actual planting. Each seedling will be marked (color-coded tubes/permanent marker) to clearly show whether the seedling is from a resistant parent tree or not. A $10 \%$ sub-sample from each seedling group will be sent to Dr. Tom Gordon’s laboratory at the University of California, Davis where seedlings will be tested for pitch canker resistance.

\section{Planting the tree:}

Seedlings will be planted 10 feet by 10 feet spacing with alternating rows of seedlings from resistant and non-resistant sources. This will create a square that is comprised of two individuals from each source. The estimated number of seedlings planted and evaluated in this experimental design is shown in Table E-1.

Table E-1

Number of Seedlings Estimation

\begin{tabular}{|c|c|c|}
\hline \multicolumn{2}{|c|}{} & $10 \times 10$ feet spacing \\
\hline \multirow{2}{*}{$\begin{array}{c}\text { Opening sizes } \\
\text { In acres }\end{array}$} & 0.5 & $1728(216)$ \\
\cline { 2 - 3 } & 0.25 & $896(112)$ \\
\hline Seedlings on Ground & 0.125 & $416(52)$ \\
\hline $10 \%$ destructive sample for PC & 3040 \\
\hline $20 \%$ cull & 434 \\
\hline \multicolumn{2}{|c|}{ Total seedlings needed } & 869 \\
\hline
\end{tabular}




\section{Sampling:}

Sample all planted seedlings for survival rate between resistant versus nonresistant.

For natural regeneration and growth, stratified sample plots will be used.

Sampling plots will be a circular plot with radius of 2.5 meters (8.12 feet). The center of the circular sampling plot will be the center of the squares created by planted seedlings (see Figure E-2). The openings will be stratified (by aspect and distance to center), and sample plots will be randomly selected from each stratified area of opening.

Selected sample plots will be clearly marked with stakes on ground. Data will be collected every three months for the first year then annually thereafter.
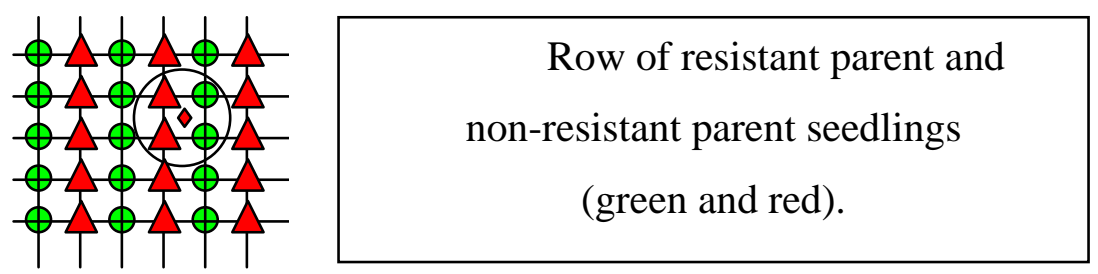

Fig. E-2. Sampling Plot Location.

\section{PreHarvest Evaluation}

The following characteristics will be evaluated in all proposed group selection treatment and control units prior to harvest:

- Pitch canker rating for all Monterey pine trees within the group selection area

- Pitch canker soil bioassay 
- Extent of Monterey pine natural regeneration

- Species composition and extent of cover

- Fuel loading

Species composition, extent of cover, and amount of Monterey pine natural regeneration will be evaluated using the sampling plot procedure described above.

\section{Post Harvest Evaluation}

Post harvest evaluation will:

- Tagging, counting, and evaluating pitch canker resistance of all naturally regenerated and planted Monterey pine

- Seedling measurements: year first observed, diameter, height, pitch canker rating, and distance to edge

- Brush species composition and extent of cover

- Fuel loading

- Pitch canker soil bioassay

\section{Other Works}

In addition to specified work above, it may be necessary to:

- Construct/install an electric fence around all planted and control areas to minimize wild boar damage.

- Control competing brush in group selection cut areas. This will only be done if necessary. 
- Remove a 3 inch cross section from base of the bottom log of all felled Monterey pine trees in the group selection cuts. This sub-study will be done to evaluate Monterey pine age structure. Dr. Scott Stephens will assist with this sub-study. 